\title{
Identification of Potential SARS-CoV-2 Main Protease and Spike Protein Inhibitors from the Genus Aloe: An In Silico Study for Drug Development
}

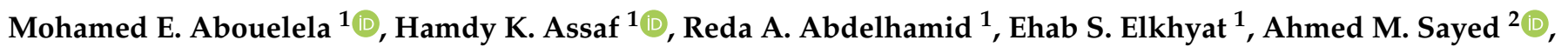 \\ Tomasz Oszako ${ }^{3}\left(\mathbb{D}\right.$, Lassaad Belbahri ${ }^{4, *(\mathbb{D})}$, Ahmed E. El Zowalaty ${ }^{5,6, *(\mathbb{D})}$ \\ and Mohamed Salaheldin A. Abdelkader ${ }^{7, *}$
}

check for updates

Citation: Abouelela, M.E.; Assaf, H.K.; Abdelhamid, R.A.; Elkhyat, E.S.; Sayed, A.M.; Oszako, T.; Belbahri, L.; El Zowalaty, A.E.; Abdelkader, M.S.A. Identification of Potential SARSCoV-2 Main Protease and Spike Protein Inhibitors from the Genus Aloe: An In Silico Study for Drug Development. Molecules 2021, 26, 1767. https://doi.org/10.3390/ molecules 26061767

Academic Editors: Shugeng Cao, Mostafa Rateb and Jianguang Luo

Received: 24 February 2021

Accepted: 18 March 2021

Published: 21 March 2021

Publisher's Note: MDPI stays neutral with regard to jurisdictional claims in published maps and institutional affiliations.

Copyright: (c) 2021 by the authors. Licensee MDPI, Basel, Switzerland. This article is an open access article distributed under the terms and conditions of the Creative Commons Attribution (CC BY) license (https:/ / creativecommons.org/licenses/by/ $4.0 /)$.
1 Department of Pharmacognosy, Faculty of Pharmacy, Al-Azhar University, Assiut-Branch, Assiut 71524, Egypt

2 Department of Pharmacognosy, Faculty of Pharmacy, Nahda University, Beni-Suef 62513, Egypt

3 Department of Forest Protection, Forest Research Institute, 05-090 Sekocin Stary, Poland

4 Laboratory of Soil Biology, University of Neuchatel, 2000 Neuchatel, Switzerland

5 Sahlgrenska Center for Cancer Research, Department of Surgery, Institute of Clinical Sciences, University of Gothenburg, 40530 Gothenburg, Sweden

6 Wallenberg Centre for Molecular and Translational Medicine, University of Gothenburg, 40530 Gothenburg, Sweden

7 Department of Pharmacognosy, Faculty of Pharmacy, Sohag University, Nasr City, Sohag 82524, Egypt

* Correspondence: lassaad.belbahri@unine.ch (L.B.); ahmed.el.zowalaty@gu.se (A.E.E.Z.); m.salaheldin@pharm.sohag.edu.eg (M.S.A.A.)

Abstract: Severe acute respiratory syndrome coronavirus (SARS-CoV-2) disease is a global rapidly spreading virus showing very high rates of complications and mortality. Till now, there is no effective specific treatment for the disease. Aloe is a rich source of isolated phytoconstituents that have an enormous range of biological activities. Since there are no available experimental techniques to examine these compounds for antiviral activity against SARS-CoV-2, we employed an in silico approach involving molecular docking, dynamics simulation, and binding free energy calculation using SARS-CoV-2 essential proteins as main protease and spike protein to identify lead compounds from Aloe that may help in novel drug discovery. Results retrieved from docking and molecular dynamics simulation suggested a number of promising inhibitors from Aloe. Root mean square deviation (RMSD) and root mean square fluctuation (RMSF) calculations indicated that compounds 132, 134, and 159 were the best scoring compounds against main protease, while compounds 115, 120, and $\mathbf{1 3 1}$ were the best scoring ones against spike glycoprotein. Compounds $\mathbf{1 2 0}$ and $\mathbf{1 3 1}$ were able to achieve significant stability and binding free energies during molecular dynamics simulation. In addition, the highest scoring compounds were investigated for their pharmacokinetic properties and drug-likeness. The Aloe compounds are promising active phytoconstituents for drug development for SARS-CoV-2.

Keywords: COVID-19; SARS-CoV-2; Aloe; docking; MD simulation; main protease; spike glycoprotein

\section{Introduction}

SARS-CoV-2, a novel coronavirus disease caused by Severe Acute Respiratory Syndrome Coronavirus 2, an RNA $\beta$-coronavirus, poses an increasing threat to human health. To date, SARS-CoV-2 has infected 105 million people worldwide (https:/ / www.worldometers.info/, accessed on 20 February 2021). The disease is manifested by fever, cough, dyspnea and pneumonia with unknown etiology that worsens over time and can lead to death [1,2]. In addition, SARS-CoV-2 patients develop low levels of neutralizing antibodies leading to prolonged disease [3]. Entry of SARS-CoV-2 into host cells is a critical factor in its pathogenesis. The surface-anchored spike proteins of SARS-CoV-2 are key determinants of viral entry. They 
bind to surface receptors on host cells, then the virus enters endosomal pathway followed by fusion of viral and lysosomal membranes [4,5]. SARS-CoV-2 spike protein has N-terminus S1 domain, a receptor binding domain (RBD) that recognizes and binds angiotensin-converting enzyme 2 (ACE2) [6-8]. Proteolytic activation of SARS-CoV-2 spike proteins is mediated by the cell surface protease TMPRSS2, a process crucial for membrane fusion and viral entry [9]. Recent studies have shown that viral entry depends on the component of the head spike that recognizes the ACE2 receptor. In addition, structural and energetic analysis have shown that high-frequency contacts between ACE2 and SARS-CoV-2 spike protein lead to local conformational stability and large energetic cost was required for virus-cell collision at early stage facilitating cell entry $[8,10,11]$.Coronavirus main protease $\left(\mathrm{M}^{\mathrm{pro}}\right.$, also known as $\left.3 \mathrm{CL}^{\text {pro }}\right)$, is the best characterized drug target, with no known human protease having the same cleavage pattern, so its inhibition leads to specific blockade of viral replication [12]. Spike glycoprotein (S protein) and its RBD are important targets for therapeutic intervention that target host cell recognition and the membrane fusion process [13]. As a global health emergency, abundant collaborative efforts have rapidly emerged to investigate the effectiveness of different therapies as antiviral, monoclonal antibodies, immune-therapies, and vaccines [14]. Current antiviral therapies for other viruses as SARS-CoV-1, MERS-CoV and HIV as well as antimalarial drugs have been inspected for their activity against SARS-CoV-2. For instance, the antimalarial drug hydroxychloroquine blocks viral cell entry by inhibiting glycosylation of host receptors and proteolytic processing. In addition, the antiviral Favipiravir inhibits RNA polymerase and is involved in entry blocking. Both drugs showed potential in vitro activity against SARS-CoV-2 [15].

Although at least six SARS-CoV-2 vaccines have been developed and licensed for emergency use, the safety, efficacy, durability and availability to large populations have not been established, so it is too early to know if COVID-19 vaccines will provide long-term protection. In addition, there is still no effective drug therapy for SARS-CoV-2. The current therapeutic strategies depend on supportive therapy and symptomatic management. Natural products can serve as prophylactic agents, halt virus progression, inhibit inflammatory cytokines secretion, and reduce infection, complications and mortality of SARS-CoV-2 [16].

Natural products have been a valuable source of therapeutic agents, molecules with therapeutic potentials, and an important source of more efficient drugs that are based on the chemical structure of natural products. For example, flavonoids have shown significant antiviral activities [17]. Curcumin and luteolin also show therapeutic potential against HIV targeting viral protease and HIV-1 transactivator of transcription [18,19]. Kaempferol also exhibits anti HSV-1 and 2 activities [20,21] Aloe is an ancient common plant species used as a medicinal plant. The genus Aloe comprises about 581 species. Its pharmacological properties and phytochemical characteristics have been extensively studied and evaluated [22]. Previous studies have shown that natural products from Aloe possess anti-inflammatory, immunostimulant, anti-cancer, antioxidant, anti-ageing, wound healing, antifungal, antibacterial and antiviral activities [23]. Natural products from Aloe showed antiviral and inhibitory activities against HSV-1 and 2, human cytomegalovirus (HCMV), influenza A, polio and other hemagglutinating viruses [23-25]. Aloin, a major compound of Aloe species, significantly reduces influenza viruses replication including oseltamivir-resistant (H1N1) influenza virus [26]. This indicates that Aloe genus offer a rich source of potential anti-viral compounds.

Virtual screening and molecular modeling studies showed potential therapeutic activities of some natural products in inhibiting SARS-CoV-2 proteins including the main protease $\left(\mathrm{M}^{\text {pro }}\right)$, spike glycoprotein (S) and angiotensin converting enzyme-2 (ACE2) receptor which are promising potential therapeutic targets [22,27]. In the present study, we conducted computational screening and molecular dynamics study on a library of isolated molecules from Aloe genus, investigated the binding affinity of these compounds with SARS-CoV-2 main protease (M ${ }^{\text {pro }}$ ), spike glycoprotein (S) through molecular docking analysis. We found six potential inhibitors from Aloe genus that effectively bind to SARS-CoV-2 
main protease $\left(\mathrm{M}^{\text {pro }}\right)$, and three inhibitors that effectively bind spike glycoprotein receptor binding domain-ACE2 interface.

\section{Results and Discussion}

\subsection{Phytochemical Constituents of Aloe}

The tested library of active constituents from Aloe genus comprised phytochemicals that cover major classes of natural products (Figure 1). Phytochemical studies of the genus Aloe plants showed the presence of anthraquinones, chromones, coumarins, flavonoids, simple phenolic compounds, phenyl pyrans and phenyl pyrones, benzofurans, naphthalene derivatives, alkaloids and fatty acid derivatives (Table A1 and Figures S1-S18). Out of 237 compounds compiled in the library; anthraquinones were the most abundant constituents, with a percentage of $36.29 \%$, followed by chromones $(27.43 \%$ ) and simple phenolic compounds $(7.17 \%)$, while alkaloids, coumarin and fatty acid derivatives constituents were less abundant.

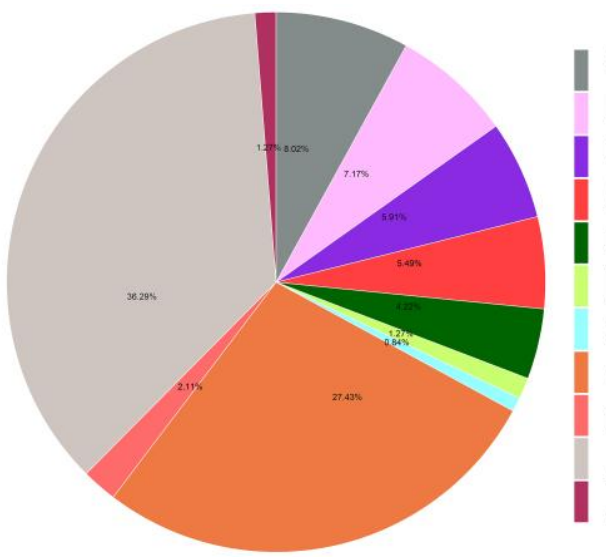

Simple phenolic compounds Phenyl-pyran and phenyl-pyrone derivatives Naphthalin derivatives Miscellaneous compounds Flavonoids Fatty acid derivatives Coumarins Chromones Benzofurans Anthraquinones Alkaloids

Figure 1. The percentage of different classes of phytochemicals reported from the genus Aloe. Anthraquinones $36.3 \%$, chromones $27.4 \%$, coumarin $0.8 \%$, flavonoids $4.2 \%$, simple phenolic compounds $8 \%$, phenyl pyran and phenyl pyrone derivatives $7 \%$, benzofurans $2 \%$, naphthalene derivatives $5.9 \%$, alkaloids $1.2 \%$, fatty acid derivatives $1.2 \%$ and miscellaneous compounds $5.5 \%$.

\subsection{Structure-Based Virtual Screening and Molecular Docking of Aloe Phytochemicals on SARS-CoV-2 Spike Glycoprotein and Main Protease}

High-throughput virtual screening of compounds from Aloe, was followed by molecular docking and MD simulation. Since ligand binding to a protein of interest is the first step in drug discovery, molecular docking is widely used to predict and identify ligands that fit into the binding pocket of a protein of interest [28]. Our screening was performed against two major drug discovery and therapeutic targets of SARS-CoV-2, spike glycoprotein and $\mathrm{M}^{\text {pro }}$ proteins [7,12]. SARS-CoV-2 main protease $\mathrm{M}^{\text {pro }}$ is critical for the life cycle of the virus. Approximately, two thirds of the SARS-CoV-2 genome is translated into polyproteins ppla and pplab, that are cleaved with $\mathrm{M}^{\text {pro }}$ into nonstructural proteins that are involved in the production of viral membrane, spike and nucleocapsid proteins [29]. $\mathrm{M}^{\text {pro }}$ is a dimer that has cysteine and histidine in the active site which form a catalytic dyad, conserved among coronaviruses making it an ideal therapeutic target [12]. In molecular docking studies, the ligand-receptor interaction with protein active site residues is established by formation of some interactions including hydrogen bonds, Van der Waal force interaction, $\pi$-sigma bond, $\pi-\pi$ interaction, electrostatic interaction, and many other hydrophobic interactions. Hydrogen bonds are essential for interaction, lowering the binding energy and stabilizing the ligand-receptor docked complex. Pharmacologically, it is well-known that blockade of a receptor active site by a ligand terminates its functional activity [30]. Our molecular docking approach was validated by docking of hydroxychloroquine, a potent inhibitor of SARS-CoV-2 Mpro. Hydroxychloroquine acts as a lysomotropic agent that inhibits viral 
entry and viral endocytosis. Viral entry and replication are highly dependent on the acidic $\mathrm{pH}$ of lysosomes and endosomes, and some host proteases which are also active in acidic $\mathrm{pH}$ (pH 5-5.5) [31]. Chloroquine and its analogues are diprotic weak bases that in their unprotonated forms, readily diffuse through cellular and organelle membranes such as lysosomes, endosomes and Golgi vesicles increasing $\mathrm{pH}$ from 6.3 to 6.7 [32-34]. In addition to disruption of endocytic pathway $\mathrm{pH}$, chloroquine and hydroxychloroquine have been recently found to be potent inhibitors of SARS-CoV-2 Mpro but not viruses that belong to Rhabdoviridae [35]. In our study, the compounds previously isolated from Aloe plants were virtually screened against SARS-CoV-2 main protease Mpro (PDB ID: 6LU7) (Figure 2) and spike glycoprotein (PDB ID: 6M0J) (Figure 2) to find potential inhibitors for SARS-CoV-2. Using our docking approach, hydroxychloroquine interacted with SARS-CoV-2 protein $\mathrm{M}^{\text {pro }}$ and docked hydroxychloroquine bound to the active site with and RMSD of $1.2 \AA$. Molecular docking data were filtered to remove compounds with scores $>-6.5$ for both SARS-CoV-2 main protease Mpro (Figure 3 and Table A1) and spike glycoprotein (Figure 4 and Table A1). Molecular docking was performed by examining the interactions of these compounds with the active site residues of these proteins and analysis of results.
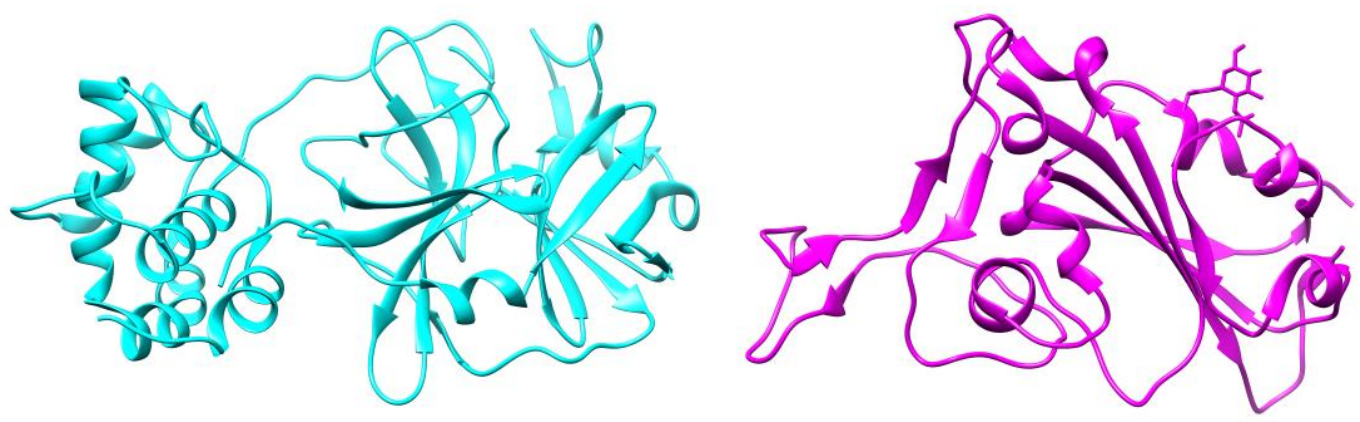

Figure 2. Three-dimensional crystal structure of the therapeutic targets of SARS-CoV-2 M $\mathrm{M}^{\text {pro }}$ main protease (PDB ID: 6LU7, cyan) and spike glycoprotein (PDB ID: 6M0J, magenta).

Compounds scoring lower than $-5.00 \mathrm{kcal} / \mathrm{mol}$ are expected to be active. These compounds were then filtered by RMSD value [30], to evaluate experimental stability of the docked ligand conformers. RMSD values around $1.5 \AA$, are considered successful and stable while those beyond $2 \AA$ indicate instability of ligand conformation and docking parameters [36]. For SARS-CoV-2 protein $\mathrm{M}^{\text {pro }}$, the binding energy observed for these compounds ranged from -7.950 to $-0.339 \mathrm{kcal} / \mathrm{mol}$ while for spike glycoprotein, binding energy ranged from -8.088 to $-5.437 \mathrm{kcal} / \mathrm{mol}$. The top three scoring compounds for SARS-CoV-2 protein $\mathrm{M}^{\text {pro }}$ were compound 132 (2'-oxo-2'-O-(3,4-dihydroxy-E-cinnamoyl)$\left(2^{\prime} R\right)$ aloesinol-7-methyl ether), compound 134 (2'-oxo-2'-O-(4-hydroxy-3-methoxy- $(E)$ cinnamoyl)-( $\left.2^{\prime} R\right)$-aloesinol-7-methyl ether) and compound 159 (rutin), (Table 1 docking scores and Figure 5, top panel). These three compounds showed the strongest interaction with the active site of SARS-CoV-2 protein M $\mathrm{M}^{\text {pro }}$. Molecular 2D and 3D interactions complexes of compounds 132, 134 and 159 with SARS- SARS-CoV-2 protein $\mathrm{M}^{\text {pro }}$ are shown in Figure 6.

On the other hand, the top three scoring compounds for SARS-CoV-2 spike glycoprotein were compounds compound 115 (2"-O-(4-methoxycinnamoyl)-(S)-aloesinol), compound 120 (rabaichromone), and compound 131 (aloeribide), (Table 1 docking score, and Figure 5, lower panel). 


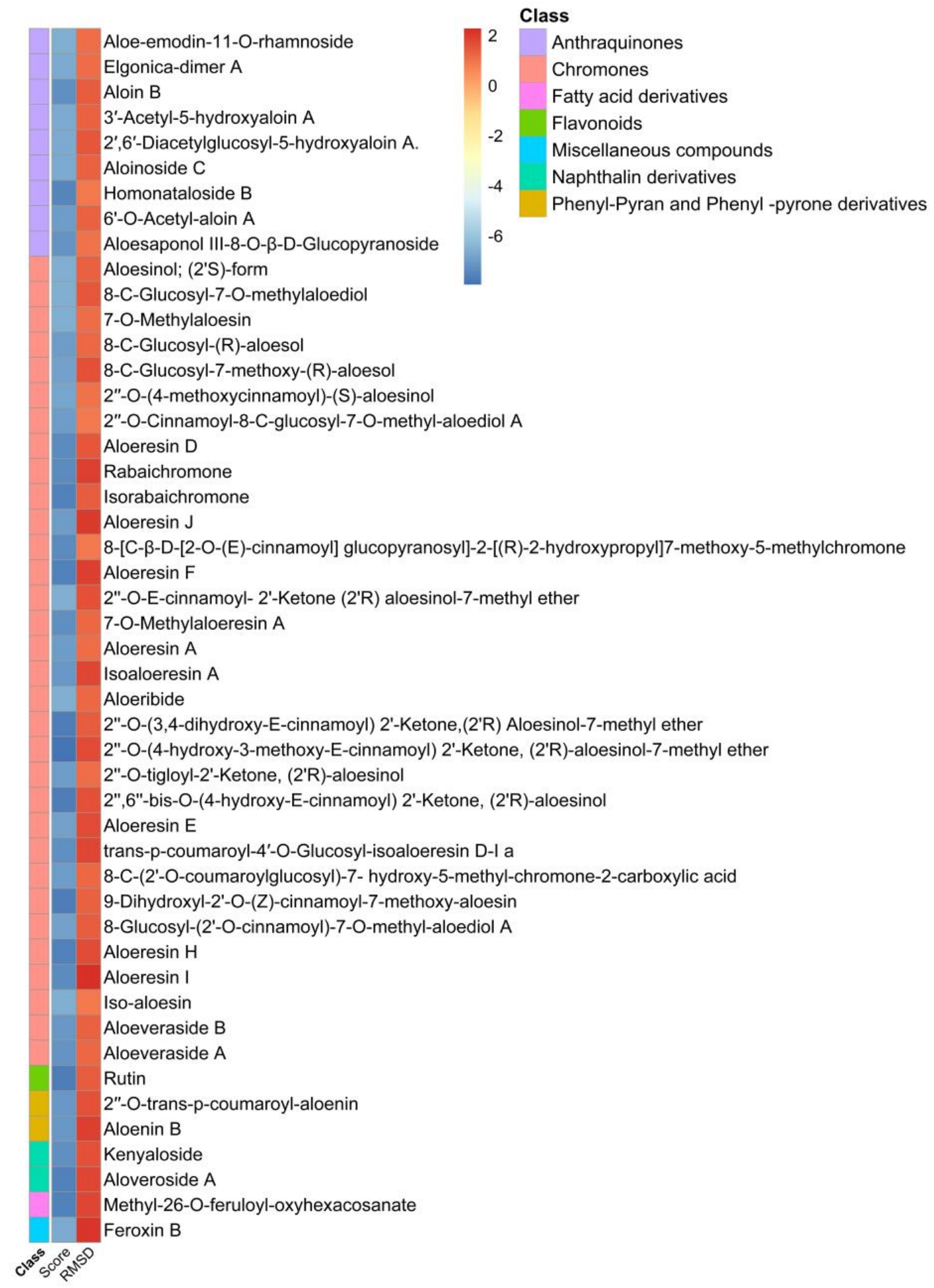

Figure 3. Docking scores and RMSD values of isolated compounds from Aloe genus against SARS-CoV-2 main protease Mpro.

These three compounds showed the strongest interaction with SARS-CoV-2 RBD. Molecular 2D and 3D interactions complexes of compounds 115, 120 and 131 with SARSSARS-CoV-2 protein spike glycoprotein receptor binding domain are shown in Figure 7. In depth analysis showed that chromone derivatives $\mathbf{1 3 2}$ and $\mathbf{1 3 4}$ had high binding affinity as lead compounds for developing SARS-CoV-2 $\mathrm{M}^{\text {pro }}$ inhibitors. These compounds had a score of $-7.683 \mathrm{kcal} / \mathrm{mol}(\mathrm{RSMD}=1.37)$ and $-7.951 \mathrm{kcal} / \mathrm{mol}(\mathrm{RSMD}=1.72)$, respectively (Table 1). 


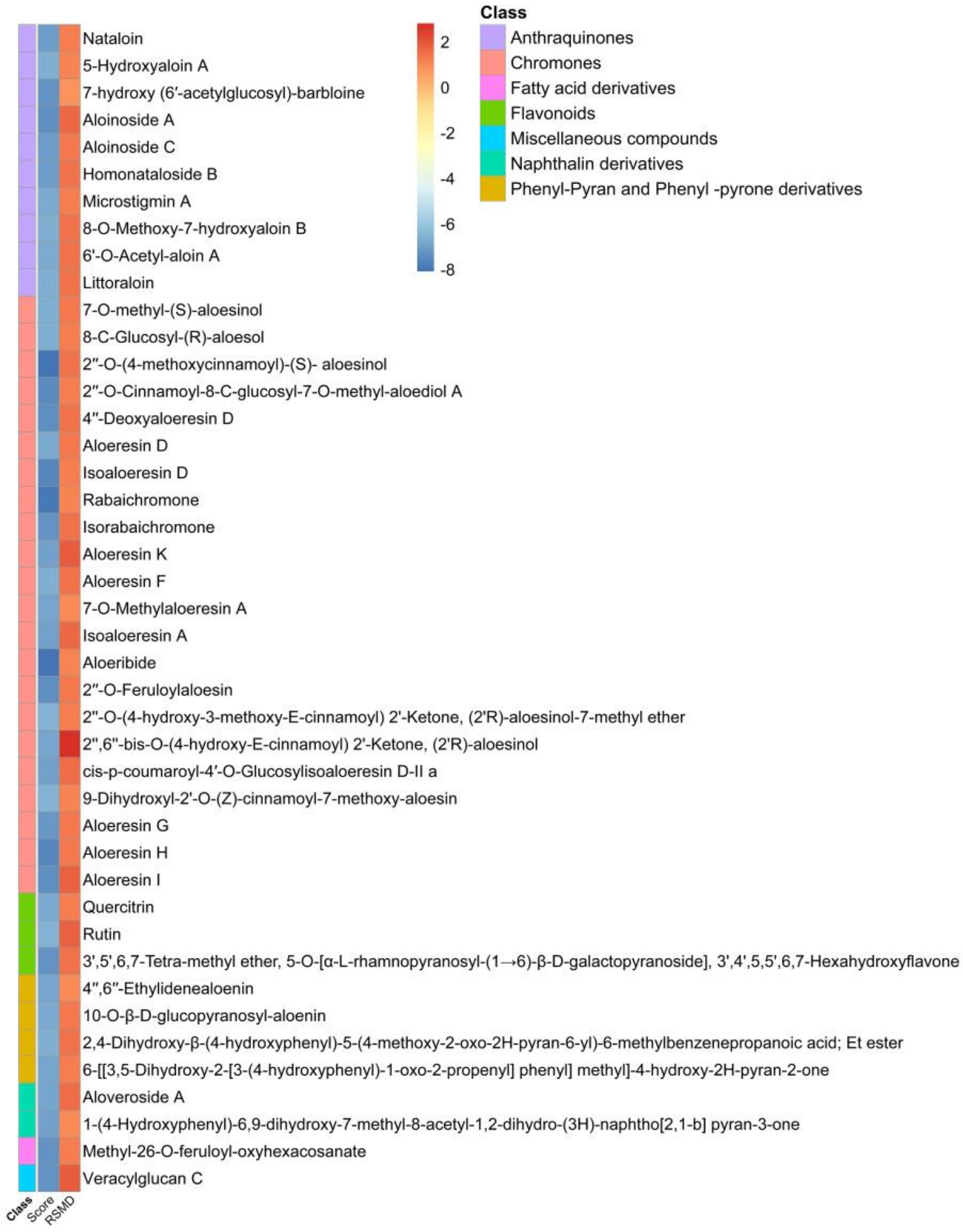

Figure 4. Docking scores and RMSD values of isolated compounds from Aloe genus against SARS-CoV-2 spike glycoprotein. 
Table 1. Molecular docking results and interactions of the three top scoring compounds of Aloe species with SARS-CoV2 proteins.

\begin{tabular}{|c|c|c|c|c|c|c|c|c|}
\hline Protein & No. & $\begin{array}{c}\text { Docking } \\
\text { Score (kcal/mol) }\end{array}$ & $\begin{array}{c}\text { RSMD }^{1} \\
\text { Refine }\end{array}$ & CLogP & Receptor & Interaction & Distance & $\begin{array}{c}\mathrm{E} \\
(\mathrm{kcal} / \mathrm{mol})\end{array}$ \\
\hline \multirow{10}{*}{$\begin{array}{l}\text { main Protease } \\
\text { (PDB ID: 6LU7) }\end{array}$} & 132 & -7.68 & 1.37 & 0.25 & ASN142A & H-donor & 3.01 & -1.9 \\
\hline & & & & & ASN142A & H-donor & 2.81 & -2.5 \\
\hline & & & & & HIS163A & H-acceptor & 3.35 & -0.7 \\
\hline & & & & & GLN189A & H-acceptor & 3.03 & -1.4 \\
\hline & & & & & GLU166A & pi-H & 4.42 & -0.7 \\
\hline & & & & & GLN189A & pi-H & 3.62 & -0.6 \\
\hline & 134 & -7.95 & 1.72 & 0.69 & ASN142A & H-donor & 3.44 & -0.6 \\
\hline & & & & & ASN142A & H-donor & 2.78 & -2 \\
\hline & & & & & HIS163A & H-acceptor & 3.29 & -1.2 \\
\hline & 159 & -7.72 & 1.40 & -1.36 & THR190A & H-donor & 2.94 & -0.8 \\
\hline \multirow{11}{*}{$\begin{array}{l}\text { Spike Glycoprotein } \\
\text { (PDB ID: 6M0J) }\end{array}$} & 115 & -8.05 & 1.49 & 1.21 & TRP566A & H-acceptor & 2.93 & -2.4 \\
\hline & & & & & LYS562A & H-acceptor & 3.11 & -12.2 \\
\hline & & & & & LYS562A & Ionic & 3.11 & -3.8 \\
\hline & & & & & VAL209 & pi-H & 4.17 & -0.6 \\
\hline & & & & & VAL209 & pi-H & 4.27 & -0.6 \\
\hline & 131 & -8.08 & 1.13 & 1.02 & GLN102A & H-donor & 3.01 & -1.2 \\
\hline & & & & & ASN210A & H-acceptor & 3.31 & -0.8 \\
\hline & & & & & ASP206A & pi-H & 4.26 & -0.7 \\
\hline & 120 & -7.87 & 1.17 & 0.46 & ALA396A & H-donor & 2.56 & -0.5 \\
\hline & & & & & ASP206A & H-donor & 2.78 & -3.0 \\
\hline & & & & & GLU208A & H-donor & 2.77 & -1.1 \\
\hline
\end{tabular}

${ }^{1}$ RMSD; Root mean square deviation.

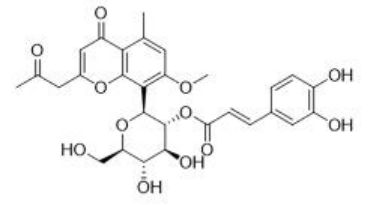

Compound No. 132: 2"-O-(3,4dihydroxy-E-cinnamoyl) 2'Ketone, (2'R) Aloesinol-7-methyl<smiles>COc1ccc(/C=C/C(=O)O[C@@H]2[C@H](c3c(O)cc(C)c4c(=O)cc(C(C)[C@H](C)O)oc34)O[C@H](CO)[C@H](O)[C@H]2O)cc1</smiles>

ồ

Compound No. 115: 2"-O-(4methoxycinnamoyl)-(S)aloesinol

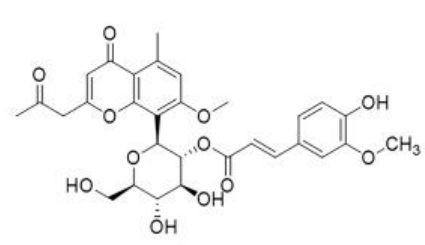

Compound No. 134: 2"-O-(4hydroxy-3-methoxy-E-cinnamoyl) 2'-Ketone, (2'R)-aloesinol-7-

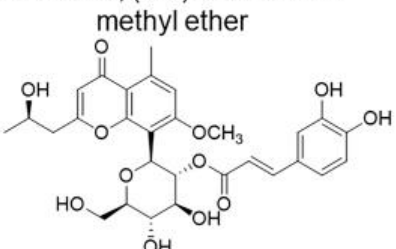

ŌH

Compound No. 120 Rabaichromone

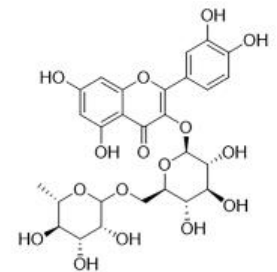

Compound No. 159 Rutin

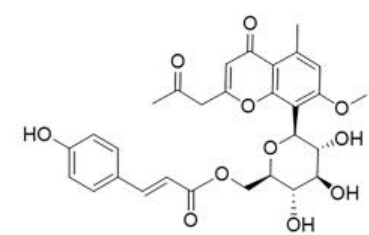

Compound No. 131 Aloeribide

Figure 5. Chemical structures of top scoring active compounds from Aloe genus. Top panel, top scoring active compounds for SARS-CoV-2 protein Mpro. Lower panel, top scoring active compounds for SARS-CoV-2 protein spike glycoprotein.

The interacting residues of SARS-CoV-2 Mpro involved in interactions with compound 132 were ASN142A, ASN142A, HIS163A, GLN189A, GLU166A and GLN189A (Figure 6A1,B1 and Table 1), while compound 134 interacted with ASN142A, ASN142A and HIS163 (Figure 6A2,B2 and Table 1). In addition, the flavonoid compound 159 forms a hydrogen bond with the M ${ }^{\text {pro }}$ protein THR190A amino acid residue with $-7.728 \mathrm{kcal} / \mathrm{mol}$ as scoring value (Figure 6A3,B3 and Table 1). Regarding the interaction of the compounds with SARS-CoV-2 spike glycoprotein, this was mainly supported by hydrogen bonds, $\pi-\mathrm{H}$, ionic and hydrophobic interactions. The highest scoring compounds were the chromone derivatives 115 (2"-O-(4-methoxycinnamoyl)-(S)-aloesinol), 120 (rabaichromone) and 131 (aloeribide) with binding energies $-8.057,-7.871$ and $-8.088 \mathrm{kcal} / \mathrm{mol}$, respec- 
tively. Compound 115 interacted with SARS-CoV-2 RBD TRP566A, LYS562A, LYS562A and VAL209 (Figure 7A1,B1 and Table 1). Moreover, compound 131 interacted with GLN102A, ASN210A and ASP206A (Figure 7A2,B2 and Table 1) by $\pi$ i- $\mathrm{H}$ bond while compound $\mathbf{1 2 0}$ formed hydrogen bonds with ALA396A, ASP206A and GLU208A amino acid residues (Figure 7A3,B3 and Table 1).
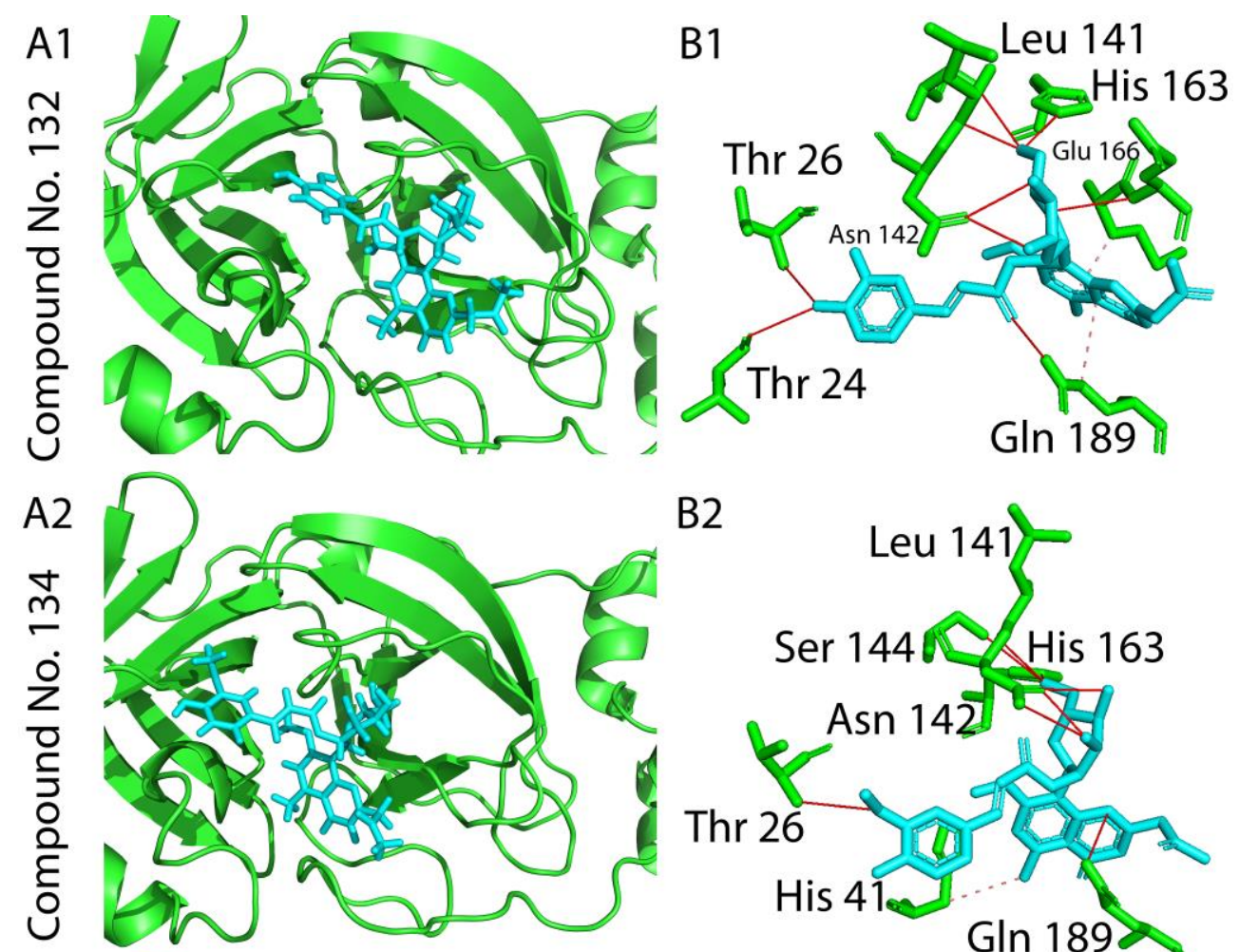

B2
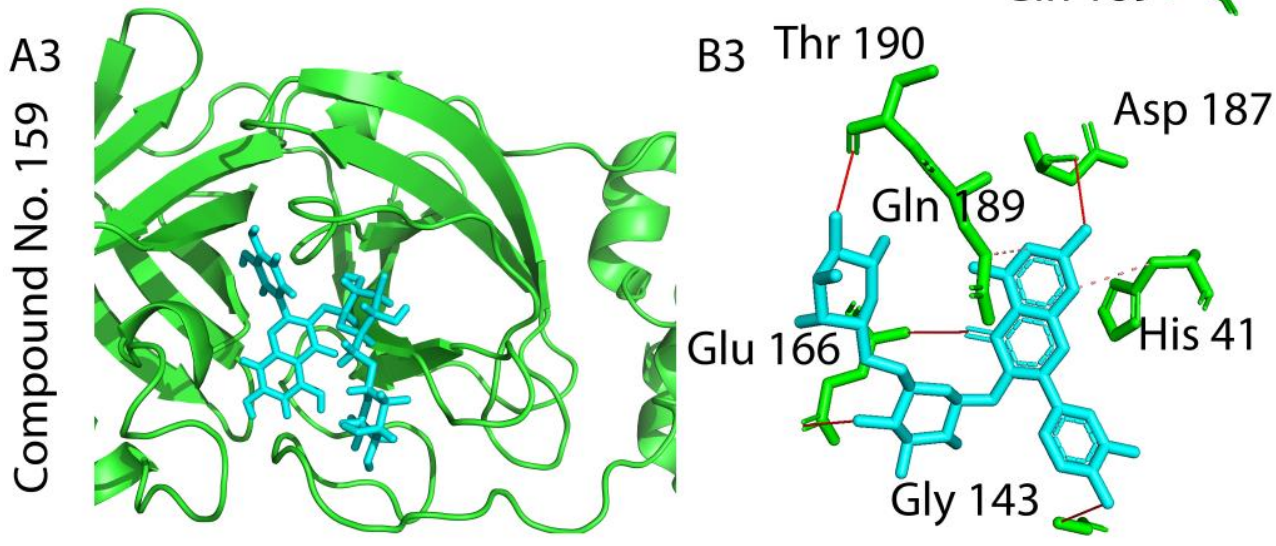

Figure 6. 2D and 3D docking interactions complexes of compounds; 132 (A1,B1), 134 (A2,B2) and 159 (A3,B3) with SARS-CoV-2 main protease protein $\mathrm{M}^{\text {pro }}$. Solid red line: Hydrogen bonds. Dashed pink line: Hydrophobic interactions. 


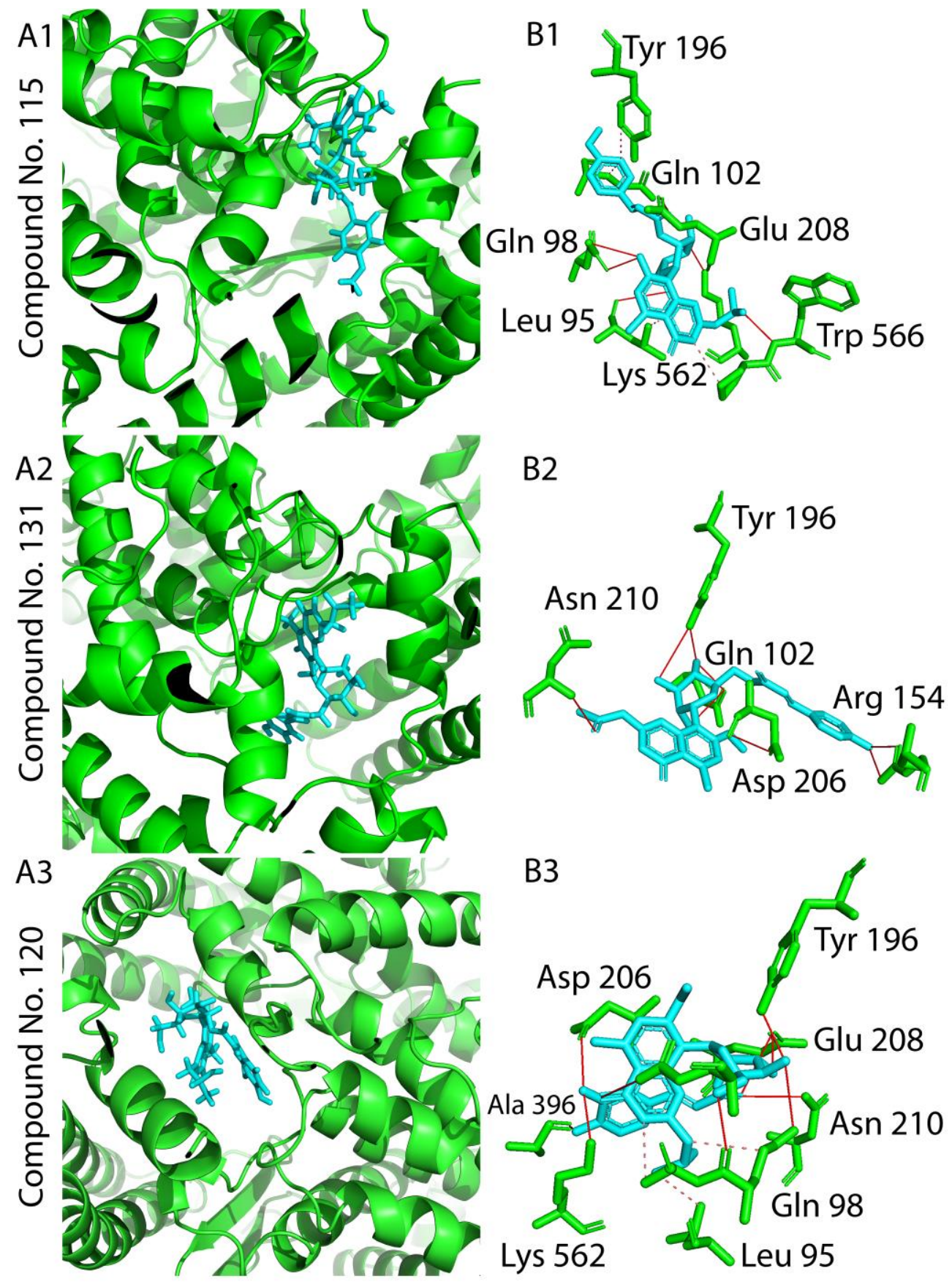

Figure 7. 2D and 3D docking interactions complexes of compounds 115 (A1,B1), 131 (A2,B2), and $120($ A3,B3) with SARS-CoV-2 spike glycoprotein. Solid red line: Hydrogen bonds. Dashed pink line: Hydrophobic interactions.

\subsection{Molecular Dynamics Simulation}

Conventional docking approaches do not account for the inherent protein binding site flexibility and the many protein conformational rearrangements [37]. Computational tools for drug discovery such as molecular dynamics take into account structural flexibility and entropic effects which produce accurate predictions of small molecule-protein binding thermodynamics and kinetics [38]. Hence dynamical docking considers flexibility of drug-protein binding and conformational changes, solvation of drug-protein complex and temperature $[38,39]$. Unbiased millisecond-long can predict spontaneous drug-protein entire binding [40]. In addition, recent developments in dynamical docking such as enhanced sampling for dynamical docking, path-based and alchemical transformations have greatly 
impacted drug discovery [38]. To validate molecular docking results, we subjected the top scoring compounds to unbiased molecular dynamics simulation experiments. The three top scoring $\mathrm{M}^{\text {pro }}$ inhibitor hits 132, 134, and 159 were able to achieve stable binding inside the active site with low deviations across the course of simulations (Average RMSD $=3.22$, 3.32 , and $3.86 \AA$, respectively) and convergent binding free energies ( $\Delta G=-6.9,-6.8$, and $-6.5 \mathrm{kcal} / \mathrm{mol}$, respectively), (Figure $8 \mathrm{~A}$ ).
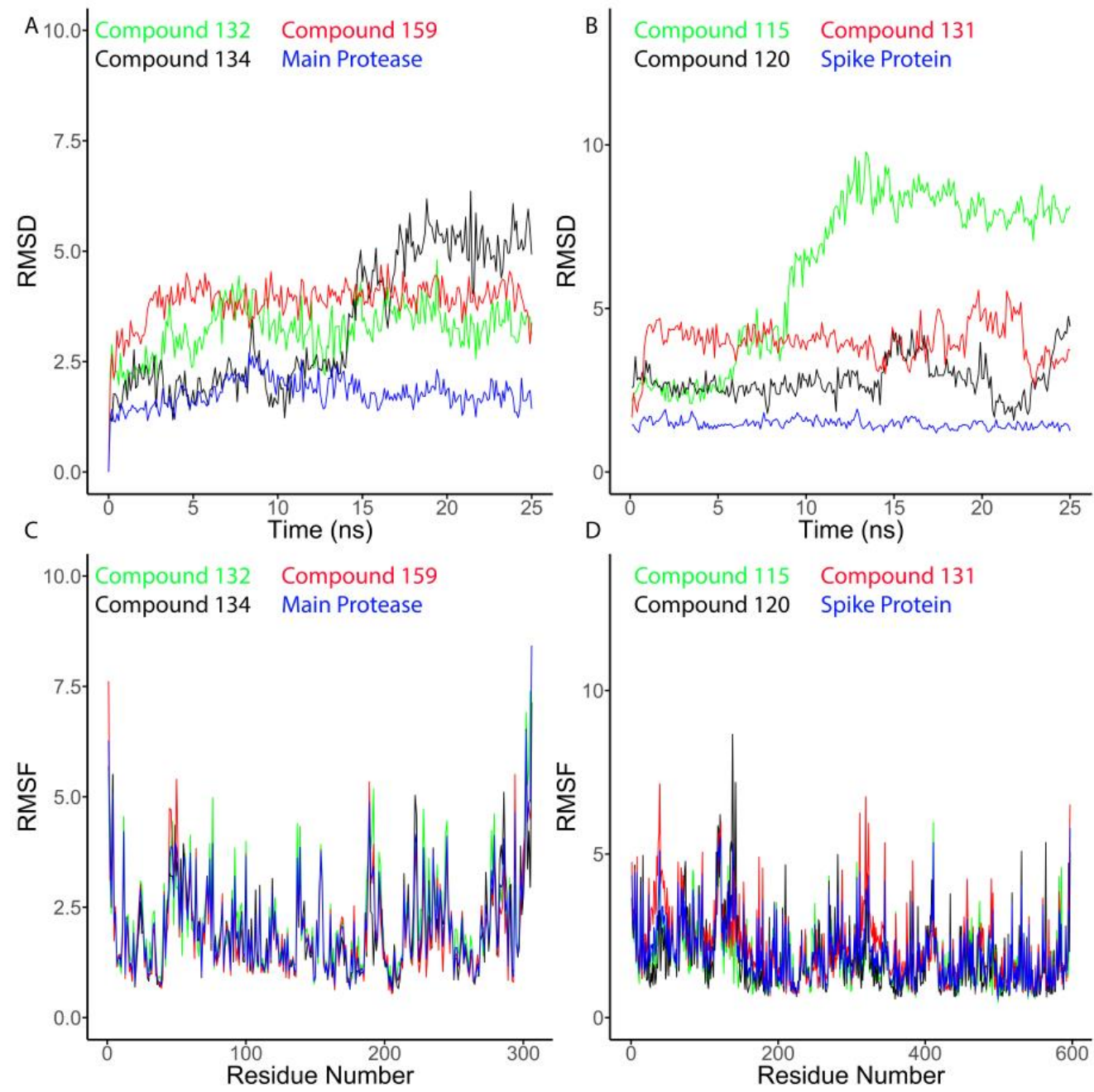

Figure 8. Analysis of the molecular dynamics (MD) simulations for top scoring compounds from Aloe genus. (A) RMSD analysis for $\mathrm{M}^{\text {pro }}$ and the ligands 132, 134 and 159. (B) RMSD analysis for spike glycoprotein and the ligands 115, 120 and 131. (C) RMSF analysis for Mpro and the ligands 132, 134 and 159. (D) RMSF analysis for spike glycoprotein and the ligands 115, 120 and 131.

With respect to SARS-CoV-2 spike glycoprotein, both compounds 120 and 131 were stable inside the binding site during MD simulation, with scoring average RMSDs of $2.81 \AA$ and $3.96 \AA$, respectively, and $\Delta \mathrm{G}$ of -7.4 and $-6.8 \mathrm{kcal} / \mathrm{mol}$, respectively (Figure $8 \mathrm{~B}$ ). On the other hand, compound 115 was significantly less stable (average RMSD = 6.2 $\AA$ ) inside the SARS-CoV-2 spike glycoprotein binding site, and this instability was further translated into a low binding free energy $(\Delta G=-4.5 \mathrm{kcal} / \mathrm{mol}$ ) compared to compounds $\mathbf{1 2 0}$ and $\mathbf{1 3 1}$ (Figure $8 \mathrm{~B}$ ). RMSF is an expression of the average residual mobility throughout simulation in a structure and a higher RMSF value indicates more flexibility during MD simulation. We calculated the RMSF value for the top scoring compounds from Aloe genus with SARSCoV-2 $\mathrm{M}^{\text {pro }}$ and SARS-CoV-2 spike glycoprotein and plotted RMSF value versus residue number (Figure 8C,D). The results indicate that compounds $\mathbf{1 5 9}$ and $\mathbf{1 2 0}$ had high RMSF values compared to other compounds. The RMSD and RMSF values indicate that the top 
scoring compounds from Aloe genus were stable and had greater random motion during the simulation. The inhibitors identified in in our docking analysis that showed interaction with SARS CoV-2 spike protein and $\mathrm{M}^{\text {Pro }}$ are in agreement with previously reported results [41]. Arokiyaraj et al. found that several polyphenolic compounds from Geranii Herba, including geraniin, kaempferitrin, quercitin, gallic acid, and kaempferol interacted with amino acid residues in the SARS-CoV-2 RBD active site inhibiting the interaction of SARS-CoV-2 RBD with ACE2. Arokiyaraj et al. also reported that these polyphenolic compounds interacted strongly with amino acids in the active site of SARS-CoV-2 M ${ }^{\text {pro }}$ and its proximity leading to blockade of the nucleophilic attack toward His 41 and blockade of proteolytic activity. In agreement with this, we found that quercetin interacted with SARS CoV-2 RBD and Mpro with binding energies of $-5 \mathrm{Kcal} / \mathrm{mol}$ and $-5.5 \mathrm{Kcal} / \mathrm{mol}$ respectively, similar to the results reported by Arokiyaraj et al. for quercetin interaction with RBD and $M^{\text {pro }}-5.71 \mathrm{Kcal} / \mathrm{mol}$ and $-6.49 \mathrm{kcal} / \mathrm{mol}$, respectively. In addition, we found that gallic acid interacted with SARS CoV-2 RBD and Mpro with binding energies of $-4.19 \mathrm{Kcal} / \mathrm{mol}$ and $-3.56 \mathrm{Kcal} / \mathrm{mol}$, respectively, similar to the binding energies reported by Arokiyaraj et al. for the gallic acid interaction with SARS CoV-2 RBD and Mpro, $-4.21 \mathrm{kcal} / \mathrm{mol}$ and $-4.46 \mathrm{kcal} / \mathrm{mol}$, respectively. These finding indicate that phenolic compounds from Aloe are potential inhibitors for SARS CoV-2 RBD and Mpro [41].

\subsection{Drug like Properties, and Pharmacokinetic Prediction of the Ligands}

Drug-like properties and pharmacokinetic properties are intrinsic characteristics of drugs that may need to be optimized independently from pharmacodynamics properties during drug development. It is a balance among molecular properties affecting pharmacodynamics and pharmacokinetics of small molecules. These molecular properties such as membrane permeability and bioavailability are always connected to some basic molecular descriptors such as lipophilicity $\log \mathrm{P}$, (Tendency of a compound to partition into an aqueous matrix versus lipid matrix), molecular weight (MW), topological polar surface area (TPSA), or hydrogen bond acceptors and donors count in a molecule. Lipophilicity impacts drug's absorption, distribution, metabolism, elimination (ADME) and plasma protein binding properties. In addition, the number of hydrogen bond donors and hydrogen bond acceptors influence drug's pKa (-log Ka). The solubility of small molecules impacts their bioavailability and the need for frequent dosing, hence we investigated the ADME properties, inhibition of cytochrome P450 (CYP), modulation of P-glycoprotein (Pgp), solubility, plasma protein binding and permeability of the top scoring compounds in our analysis. The best scoring compounds for both SARS-CoV-2 Mpro and spike glycoprotein were tested for obeying Lipinski's rule of five parameters, which states that drugs having $\log P$ ranging from 0 to 5, have high possibility of oral absorption [42]. Data (Table 2) showed that the compounds have log P values that ranged from -1.06 to 2.8 that does not exceed 5.0 indicating reasonable probability of their good absorption. The number of hydrogen bond donors was variable and ranged from 4 to10 that is more than 5 and also hydrogen bond acceptors were 11-16 that is more than 10. All compounds have number of atoms that ranged from 40 to 43 which is within 20-70. In addition, the topological polar surface area (TPSA) of the compounds as parameter for the prediction of drug transport properties showed TPSA value greater than $140 \AA^{2}$ tend to be poor at permeating cell membranes. Despite violation of some rules, approved anticancer and anti-infective drugs from natural products or their semisynthetic derivatives such as taxol and amphotericin $\mathrm{B}$ have also some violations but are biologically effective as drugs. Therefore, these results don't interfere with the development of these compounds as potential SARS-CoV-2 therapeutic agents [43]. 
Table 2. Drug-likeness and molecular properties of top scoring compounds predicted at molinspiration server. miLogP: Molinspiration LogP (Octanol-water partition coefficient); TPSA: Total polar surface area (drug transport properties); natoms-Number of atoms; Mol.Wt (g/mol): Molecular weight; nON: number of hydrogen bond acceptors; nOHHN: number of hydrogen bond donors; nviolations: Number of Lipinski's rule of five parameters violations; nrotb: Number of Rotatable Bonds (molecular flexibility).

\begin{tabular}{|c|c|c|c|c|c|c|}
\hline & 115 & 120 & 131 & 132 & 134 & 159 \\
\hline miLogP & 2.8 & 1.84 & 2.15 & 1.66 & 1.96 & -1.06 \\
\hline TPSA & 176.12 & 196.35 & 172.97 & 193.19 & 182.2 & 269.43 \\
\hline natoms & 40 & 41 & 40 & 41 & 42 & 43 \\
\hline MW & 556.56 & 572.56 & 554.55 & 570.55 & 584.57 & 610.52 \\
\hline $\mathrm{nON}$ & 11 & 12 & 11 & 12 & 12 & 16 \\
\hline $\mathrm{nOHNH}$ & 5 & 6 & 4 & 5 & 4 & 10 \\
\hline nviolations & 2 & 3 & 2 & 2 & 2 & 3 \\
\hline nrotb & 9 & 9 & 9 & 9 & 10 & 6 \\
\hline volume & 486.85 & 494.87 & 480.99 & 489.01 & 506.53 & 496.07 \\
\hline$\%$ ABS & 48.23 & 41.25 & 49.32 & 42.34 & 46.14 & 16.04 \\
\hline
\end{tabular}

Data resulting from Prediction of ADME server (Table S1) revealed that compounds $115,120,131,132,134$ may be better absorbed from the intestinal tract upon oral administration as they showed good human intestinal absorption (HIA) (77.110857, 57.614849, $82.803611,66.184384$ and 79.978975 , respectively). Caco-2 cell permeability is a model for selecting drug candidates for oral administration [44]. All compounds showed medium Caco-2 predicted permeability and medium MDCK predicted cell permeability [45]. Moreover, all compounds showed moderate predicted plasma protein binding (PPB) (Table S1) except for compound 159, which showed weak predicted PPB, which indicates predicted decreased excretion and increased predicted half-life. It is important to consider drug's interaction with plasma proteins, transporters and CYP450s for the successful selection of drug candidate. CYP2C19 and CYP2C9 inhibition leads to increased drug plasma concentration, leading to potential side effects $[46,47]$. All top scoring compounds were predicted to inhibit CYP2C19 and CYP2C9. CYP2D6 metabolizes many drugs and toxins [48]. None of the top scoring compounds showed predicted inhibitory activity to CYP2D6. CYP3A4 is also involved in metabolism of xenobiotics and is highly expressed in the liver and intestine [49]. The six top scoring compounds were predicted to inhibit CYP3A4. Drug resistance is a major concern in drug development. Multidrug resistance is regulated by a network of ATP-binding cassette $(\mathrm{ABC})$ proteins that detoxify xenobiotics and act as drug transporters and efflux pumps. P glycoprotein (Pgp; ABCB1) is the most popular and well-studied efflux pump [50,51]. Pgp has intrinsic ATPase activity to drive active transport and generate a concentration gradient leading to transport of drugs to the extracellular space and inhibition of drug activity [51]. Pgp is highly expressed in blood-brain barrier cell, liver, intestine and kidney. Thus, it is important to predict drug's binding to Pgp. Only compound 115 was predicted to inhibit Pgp and hence it may affect the activity or excretion of other Pgp substrates. Compound 159 had the highest water solubility $(217.207 \mathrm{mg} / \mathrm{L})$ while the other five compounds had low water solubility, hence this should be considered during drug development. In addition, skin permeability is an important factor to consider during drug development for the potential of dermal drug delivery and risk assessment of drugs that may contact skin [52]. Skin permeability also increases drug's plasma concentration and activity. It has been reported that $\log P$ between -3 to +6 predict drug's skin permeability [53]. SKlogD, SKlogP and SKlogS are related to drugs' skin permeability and lipophilicity. All the six top scoring compounds had skin permeability values ranging from -4.6 to -3.6 , indicating that they may not be absorbed through skin and thus should not pose a dermal exposure risk. Finally, all compounds did not have predicted ability to pass the blood brain barrier (BBB) and are not expected to be neurotoxic. 


\section{Materials and Methods}

\subsection{Phytochemical Review of Genus Aloe}

Intensive review of the literatures in ScienceDirect, PubMed, SciFinder and has been conducted to identify compounds from Aloe genus.

\subsection{Molecular Docking, Data Software and Visualization \\ 3.2.1. Preparation of Protein and Active Site Prediction}

In this study, two SARS-CoV-2 proteins which facilitate viral-host interaction and replication were selected from the RCSB protein databank (https:/ / www.rscb.org/pdb, accessed on 20 February 2021). The proteins are SARS-CoV-2 main protease (PDB ID: 6LU7, resolution $=2.16 \AA$ ) [54] and spike glycoprotein (PDB ID: 6M0J, resolution $=2.45 \AA$ ) [42]. The $3 \mathrm{D}$ protein structures were prepared using Molecular Operating Environment software (MOE 2014.0901) Ligx option. The site finder function used to calculate and predict possible active potential site of selected proteins for ligand binding in the receptor. PyMol 2.3 software was used for visualization.

\subsubsection{Preparation of Ligand}

Reviewing the available literatures identified 237 phytochemical compounds that were isolated from genus Aloe (Table A1 and Figures S1-S18). All these molecular structures were imported to $\mathrm{MOE}$ and subjected to $3 \mathrm{D}$ protonation and energy minimization using MMFF94s force field and ligand database was constructed. Ligand coordinate files were extracted from PDB files and used as reference structures for root mean square deviation (RMSD) calculations.

\subsubsection{Docking Analysis}

Flexible ligand-rigid receptor docking was performed with MOE-DOCK for molecular docking. The parameters of scoring were Triangle Matcher, scoring was set at London $\mathrm{dG}$ with 30 output poses and rescoring at GBVI/WSA dG retaining 10 refined poses. The docking score, root mean square deviation (RSMD), 2D and 3D interactions were recorded [55]. The results of docked ligands are chosen based on the most negative docking score. The docking score represents the best-bound ligand conformations and relative binding affinities. The best-docked conformations for comparison of the binding of the drugs and targets of SARS-CoV2 were selected based on number of hydrogen bonds, binding energy $(\mathrm{kcal} / \mathrm{mol})$, upper and lower bound RMSD, number of interacting residues, and forces which stabilized the receptor-ligand complex. RMSD and RMSF of the ligand interaction with the target protein were calculated using the following formulas:

$$
\begin{gathered}
\left.R M S D_{x}=\sqrt{\frac{1}{N} \sum_{i=1}^{n}\left(r_{i}^{t}\left(t_{x}\right)\right)-r_{i}\left(t_{r e f}\right)}\right)^{2} \\
\left.R M S F_{i}=\sqrt{\frac{1}{T} \sum_{t=1}^{T}<\left(r_{i}^{t}(t)\right)-r_{i}\left(t_{r e f}\right)}\right)^{2}>
\end{gathered}
$$

where $N$ is the number of atoms, $t_{r e f}$ is the reference time, $r^{\prime}$ is the position of the selected atoms in frame $x$ after superimposing on the reference frame, frame $\mathrm{x}$ recorded at time $t_{x}$ $T$ is the trajectory time over which the RMSF was calculated, $r$ is the position of an atom. Poses of docked compounds are automatically calculated by docking function in Molecular Operating Environment software.

\subsection{Molecular Dynamics Simulation}

MD simulation experiments were performed as previously described [43]. Briefly, the Molecular Dynamics (NAMD) 2.6 software [45], employing the CHARMM27 force field [56] was used for simulations. Hydrogen atoms were added to initial coordinates of proteins using the psfgen plugin included in the Visual Molecular Dynamics (VMD) 1.9 software [57]. Subsequently, the protein systems were solvated using TIP3P water particles 
and $0.15 \mathrm{M} \mathrm{NaCl}$. The equilibration procedure comprised 1500 minimization steps followed by $30 \mathrm{ps}$ of $\mathrm{MD}$ simulation at $10 \mathrm{~K}$ with fixed protein atoms. Then, the entire systems were minimized over 1500 steps at $0 \mathrm{~K}$, followed by gradual heating from 10 to $310 \mathrm{~K}$ using temperature reassignment during the initial 60 ps of the 100 ps equilibration MD simulation. The final step involved NTP simulation (30 ps) using the Nose-Hoover Langevin piston pressure control at $310 \mathrm{~K}$ and 1.013 bars for density (volume) fitting [58]. Thereafter, the MD simulation experiments were continued for $25 \mathrm{~ns}$ for the entire systems (20 ns for the enzyme-ligand complexes). The trajectory was stored every $0.1 \mathrm{~ns}$ and further analyzed with the VMD 1.9 software. The MD simulation output over $25 \mathrm{~ns}$ provided several structural conformers that were sampled every $0.1 \mathrm{~ns}$ ( 250 poses) to evaluate conformational changes of the entire protein structure to analyze the RMSD. All parameters and topologies of the compounds selected for MD simulation were prepared using the online software Ligand Reader \& Modeler [59] and the VMD Force Field Toolkit (ffTK) [57]. Binding free energy calculations $(\Delta G)$ were performed using the free energy perturbation (FEP) method through the web-based software Absolute Ligand Binder [60] together with MD simulation software NAMD 2.6 [45]. Hydrogen bonds and hydrophobic interactions between protein and ligand were also analyzed using Protein-Ligand Interaction Profiler [61].

\subsection{Drug Like Properties, and ADME Prediction of the Ligands}

The drug likeliness of best pose scoring compounds is specified by the Lipinski's rule and molecular properties prediction was calculated by the free access website https: //www.molinspiration.com/cgi-bin/properties, accessed on 20 February 2021. ADME Prediction were determined by PreADMET estimation server website [62].

\section{Conclusions}

In recent years, advances in computational resources and software tools led to emergence of molecular dynamics (docking and scoring tool), as the first phase in drug screening and discovery. In addition, absence of new cell culture models for working safely with highly pathogenic viruses makes virtual screening, docking and dynamics of great importance. Aloe genus is a rich source of phytochemicals with a wide range of therapeutic activity. Several natural products from Aloe have shown strong antiviral activity, inhibiting replication and entry and of HSV-1 and 2, human cytomegalovirus (HCMV), influenza A and polio. Aloin significantly reduces replication of oseltamivir-resistant (H1N1) influenza virus. In our study, we applied computational screening of 237 natural product compounds from Aloe genus and identification of six compounds as stable potential inhibitors of SARS$\mathrm{CoV}-2$ main protease and spike glycoprotein. Our molecular docking analysis showed that theses six compounds are stable and safe. Compounds 132, 134 and 159 were the top three scoring potential inhibitors of for SARS-CoV-2 main protease. These compounds interacted strongly with amino acids in the active site of SARS-CoV-2 main protease. Rutin (154) is known to have antiviral activity against influenza virus [63]. Compounds 115, 120 and compound 131 were the top scoring potential inhibitors of SARS-CoV-2 spike glycoprotein. The results highlighted chromone derivatives as potential inhibitors for SARS-CoV-2 according to their best scores of binding affinities to the mentioned target proteins among the examined compounds. The results of this in-silico investigation (docking and molecular dynamics simulation) should have a great impact for drug repurposing studies. In the future, in vitro, in vivo and clinical studies shall be conducted to further validate the effectiveness of these compounds as potential treatments for COVID-19 and to identify compounds with best pharmacokinetic profiles. In addition, it will be of great importance to apply newly-developed algorithms and utilize the development of steered molecular dynamics for evaluating the binding of the top scoring compounds to SARS-CoV-2 target proteins [64]. 
Supplementary Materials: The following are available online. Figures S1-S18: Compounds isolated from genus Aloe, Table S1: Predicted pharmacokinetics of top scoring compounds.

Author Contributions: Conceptualization; M.E.A. and M.S.A.A.; Data curation, E.S.E., A.M.S., T.O., L.B. and A.E.E.Z.; Formal analysis, M.E.A., R.A.A., A.M.S., L.B. and A.E.E.Z.; Investigation, M.E.A., H.K.A., R.A.A., E.S.E., A.M.S., A.E.E.Z. and M.S.A.A.; Methodology, M.E.A., H.K.A., R.A.A. and A.M.S.; Project administration, E.S.E., A.E.E.Z. and M.S.A.A.; Resources, E.S.E., T.O., L.B., A.E.E.Z. and M.S.A.A.; Software, M.E.A., H.K.A., R.A.A. and A.M.S.; Supervision, E.S.E., A.E.E.Z. and M.S.A.A.; Validation, L.B., T.O.; Visualization, M.E.A., M.S.A.A. and A.E.E.Z.; Writing-original draft, M.E.A. and H.K.A.; Writing—review \& editing, E.S.E., A.E.E.Z. and M.S.A.A. All authors have read and agreed to the published version of the manuscript.

Funding: This research received no external funding.

Data Availability Statement: Not applicable.

Conflicts of Interest: The authors declare that they have no competing financial interests or personal relationships that could influence the work reported in this paper.

Sample Availability: Samples of the compounds are not available from the authors.

\section{Appendix A}

Table A1. Docking score of isolated compounds from Aloe plants against selected SARS CoV-2 proteins.

\begin{tabular}{|c|c|c|c|c|c|c|c|}
\hline \multirow{2}{*}{ No. } & \multirow{2}{*}{ Name of the Compound } & \multicolumn{2}{|c|}{$\begin{array}{l}\text { Main Protease } \\
\text { (PDB ID: 6LU7) }\end{array}$} & \multicolumn{2}{|c|}{$\begin{array}{l}\text { Spike Glycoprotein } \\
\text { ((PDB ID: 6M0J) }\end{array}$} & \multirow{2}{*}{ Plant Source } & \multirow{2}{*}{ Ref. } \\
\hline & & Score & RSMD & Score & RSMD & & \\
\hline \multicolumn{8}{|c|}{ I-Anthraquinones: } \\
\hline 1 & Chrysophanol & -5.4584 & 0.8734 & -5.4447 & 0.8709 & $\begin{array}{l}\text { A. pulcherrima, A. dawei, } A \text {. } \\
\text { megalacantha, A. vera }\end{array}$ & [65-68] \\
\hline 2 & 8-O-Methylchrysophanol & -5.0678 & 0.4878 & -4.8406 & 0.9352 & A. dawei & {$[66]$} \\
\hline 3 & Aloe-emodin & -5.3348 & 0.8782 & -6.0546 & 0.9449 & $\begin{array}{c}\text { A. megalacantha, } A \text {. arborescens } \\
\text { A. vera, } A \text {. ferox }\end{array}$ & [67-72] \\
\hline 4 & 7-Hydroxy-aloe-emodin & -5.3660 & 1.3842 & -4.8938 & 0.9332 & A. succotrina & [73] \\
\hline 5 & Nataloe-emodin & -5.5017 & 0.7836 & -5.2599 & 0.4924 & A. nyeriensis & {$[74]$} \\
\hline 6 & $\begin{array}{l}\text { Mono-O-methyl-nataloe- } \\
\text { emodin }\end{array}$ & -4.8059 & 1.2584 & -4.6113 & 0.9158 & A. speciosa & [74] \\
\hline 7 & Emodin & -4.4060 & 0.9758 & -4.8558 & 1.3623 & A. vera, A. spp & {$[72,75-77]$} \\
\hline 8 & Saponarin II & -4.7520 & 1.0190 & -5.1119 & 1.3501 & $\begin{array}{c}\text { A. megalacantha, } A . \\
\text { pulcherrima, } A \text {. dawei, } A \text {. } \\
\text { saponaria. }\end{array}$ & {$[65-67,78-80]$} \\
\hline 9 & Saponarin I & -5.5636 & 0.8416 & -5.2625 & 1.3226 & $\begin{array}{c}\text { A. megalacantha, } A \text {. } \\
\text { pulcherrima, A. saponaria. }\end{array}$ & {$[65,67,78,81]$} \\
\hline 10 & Saponarin III & -5.5941 & 0.9280 & -5.9907 & 0.9256 & A. megalacantha & {$[67]$} \\
\hline 11 & Helminthosporin & -5.2698 & 0.6476 & -5.3963 & 1.3211 & $\begin{array}{l}\text { A. megalacantha, A. dawei, A. } \\
\text { Saponaria }\end{array}$ & {$[66,67,79]$} \\
\hline 12 & 5-O-Methylziganein & -5.6054 & 0.8884 & -3.3209 & 0.8923 & A. hijazensis & {$[82]$} \\
\hline 13 & Isoxanthorin & -4.7748 & 1.2234 & -3.9051 & 0.9124 & A. Saponaria & {$[79,80]$} \\
\hline 14 & Deoxyerythrolaccin & -4.7968 & 1.3812 & -5.2572 & 1.2640 & A. ferox, A. Saponaria & [71] \\
\hline 15 & Laccaic acid D Methyl ester & -6.1620 & 0.9956 & -5.3786 & 0.8172 & A. Saponaria, A. dawei & {$[66,78]$} \\
\hline 16 & Madagascin & -4.2212 & 1.1677 & -4.0269 & 0.9379 & A. vera & [83] \\
\hline 17 & 3-Geranyloxyemodine & -5.4161 & 1.4882 & -4.8861 & 1.1771 & A. vera & [83] \\
\hline 18 & Aloetinic acid. & -5.6006 & 1.6111 & -2.8968 & 1.3504 & A. vera & {$[84]$} \\
\hline 19 & $\begin{array}{l}\text { Nataloe-emodin-2-O- } \beta \text {-D- } \\
\text { Glucopyranoside }\end{array}$ & -5.3915 & 0.9107 & -4.4116 & 1.4211 & A. nyeriensis & [85] \\
\hline 20 & Aloe-emodin-11-O-rhamnoside & -6.5513 & 1.1442 & -6.3233 & 1.2130 & A. vera & {$[72,86]$} \\
\hline
\end{tabular}


Table A1. Cont.

\begin{tabular}{|c|c|c|c|c|c|c|c|}
\hline \multirow[t]{2}{*}{ No. } & \multirow[t]{2}{*}{ Name of the Compound } & \multicolumn{2}{|c|}{$\begin{array}{l}\text { Main Protease } \\
\text { (PDB ID: 6LU7) }\end{array}$} & \multicolumn{2}{|c|}{$\begin{array}{l}\text { Spike Glycoprotein } \\
\text { ((PDB ID: 6M0J) }\end{array}$} & \multirow[t]{2}{*}{ Plant Source } & \multirow{2}{*}{ Ref. } \\
\hline & & Score & RSMD & Score & RSMD & & \\
\hline \multicolumn{8}{|c|}{ I-Anthraquinones: } \\
\hline 21 & $\begin{array}{c}1,1^{\prime}, 8,8^{\prime} \text {-Tetrahydroxy-3,3'- } \\
\text { dimethyl-4, } 7^{\prime} \text {-bianthracene- } \\
9,9^{\prime}, 10 \\
\left(10^{\prime} H\right) \text {-trione }\end{array}$ & -6.2519 & 0.8628 & -3.7287 & 1.2329 & A. Saponaria & [81] \\
\hline 22 & Asphodelin & -5.8474 & 0.9813 & -6.1966 & 1.2760 & A. megalacantha, A. Saponaria & {$[67,81]$} \\
\hline 23 & $\begin{array}{c}\left(1,1^{\prime}, 8,8^{\prime}, 10-\text { Pentahydroxy-3,3'- }\right. \\
\text { dimethyl-10,7'-bianthracene- } \\
\left.9,9^{\prime}, 10^{\prime} \text {-trione }\right)\end{array}$ & -5.2521 & 1.3390 & -6.4419 & 1.2682 & A. Saponaria & [81] \\
\hline 24 & $\begin{array}{l}\text { 10-(chrysophanol-7'-yl)-10- } \\
\text { hydroxychrysophanol-9- } \\
\text { anthrone }\end{array}$ & -6.0946 & 1.6603 & -5.7400 & 1.2765 & A. megalacantha & {$[67]$} \\
\hline 25 & Chrysalodin & -6.3819 & 1.4365 & -5.8787 & 1.3680 & A. megalacantha & {$[67]$} \\
\hline 26 & 10-O-Methylchrysalodin & -5.1180 & 0.9839 & -5.1616 & 1.0078 & A. megalacantha & {$[67]$} \\
\hline 27 & Elgonica-dimer A & -6.6933 & 1.1067 & -2.5862 & 1.4349 & A. elgonica, A. vera & {$[87-89]$} \\
\hline 28 & Elgonica-dimer B & -6.4416 & 1.2142 & 5.4378 & 1.6013 & A. elgonica, A. vera & {$[87-89]$} \\
\hline 29 & $\begin{array}{c}1,4^{\prime}, 5^{\prime}, 8,9^{\prime} \text {-Pentahydroxy-2',6- } \\
\text { dimethyl }\left[2,9^{\prime} \text {-bianthracene]- }\right. \\
9,10^{\prime}\left(9^{\prime} H, 10 H\right) \text {-dione }\end{array}$ & -6.1595 & 1.1344 & -6.2983 & 1.4995 & A. Saponaria & {$[81]$} \\
\hline 30 & Aloin A & -6.1758 & 1.0225 & -5.8047 & 1.3500 & $\begin{array}{l}\text { A. calidophila, A. schelpei, A. } \\
\text { vera, A. perryi, A. ghibensis, A. } \\
\text { gilbertii, A. trigonantha }\end{array}$ & {$[68,69,90-96]$} \\
\hline 31 & Aloin B & -7.2794 & 1.3710 & -6.3227 & 1.1594 & $\begin{array}{l}\text { A. vera, A. perryi, A. ghibensis, } \\
\text { A. gilbertii,A. trigonantha }\end{array}$ & {$[68,69,90-92]$} \\
\hline 32 & 7-Hydroxy-8-O-methylaloin A & -6.4555 & 1.4506 & -6.1034 & 1.1466 & A. vera & [97] \\
\hline 33 & 7-Hydroxy-8-O-methylaloin B & -3.3579 & 1.4722 & -5.1135 & 1.1263 & A. vera & [97] \\
\hline 34 & Nataloin & -3.1203 & 0.9706 & -7.1048 & 1.2243 & A. nyeriensis & {$[85]$} \\
\hline 35 & 6'-O-Malonylnataloin & -6.1541 & 1.3288 & -3.4142 & 1.0014 & A. ellenbeckii & [98] \\
\hline 36 & Homonataloin A & -3.4695 & 1.0697 & -5.4443 & 1.4948 & $\begin{array}{l}\text { A. lateritia, A. distans, } A \text {. } \\
\text { cremnophila, A. citrina, A. vera }\end{array}$ & {$[92,99,100]$} \\
\hline 37 & Homonataloin B & -4.9349 & 1.4914 & -4.9807 & 0.8487 & $\begin{array}{c}\text { A. lateritia, A. excelsa, A. vera, } \\
\text { A. perryi }\end{array}$ & {$[92,99,101,102]$} \\
\hline 38 & 5-Hydroxyaloin A & -4.8766 & 1.1457 & -6.6159 & 1.1690 & A. nobilis, A microstigma & {$[99,103,104]$} \\
\hline 39 & 7-Hydroxyaloin A & -3.0164 & 1.4360 & -5.5526 & 0.9072 & A. ghibensis, A. succotrina & {$[73,91]$} \\
\hline 40 & 3'-Acetyl-5-hydroxyaloin A & -6.6767 & 1.3118 & -5.1832 & 1.2296 & A. nobilis & {$[104]$} \\
\hline 41 & $\begin{array}{l}\text { 6'-Acetylglucosyl-5- } \\
\text { hydroxyaloin A }\end{array}$ & -5.3535 & 1.3456 & -5.4990 & 1.1070 & A. marlothii,Aloe rupestris & {$[105]$} \\
\hline 42 & $\begin{array}{c}\text { 7-Hydroxy } \\
\left(6^{\prime} \text {-acetylGlucosyl)-aloin }\right.\end{array}$ & -5.2629 & 1.2352 & -6.4008 & 1.4160 & A. succotrina & {$[73,106]$} \\
\hline 43 & $\begin{array}{c}\text { 7-hydroxy } \\
\text { (6'-acetylglucosyl)-barbloine }\end{array}$ & -4.2565 & 1.4076 & -7.2279 & 0.8115 & A. succotrina & {$[73]$} \\
\hline 44 & $\begin{array}{c}2^{\prime}, 6^{\prime} \text {-Diacetylglucosyl-5- } \\
\text { hydroxyaloin A. }\end{array}$ & -6.7157 & 1.5569 & -5.8313 & 1.3241 & A. nobilis & {$[104]$} \\
\hline 45 & $\begin{array}{c}4^{\prime}, 6^{\prime} \text {-Diacetylglucosyl-5- } \\
\text { hydroxyaloin A }\end{array}$ & -4.9825 & 1.7716 & -5.7746 & 1.0670 & A. nobilis & {$[104]$} \\
\hline 46 & 8-O-Methoxy-7-hydroxyaloin A & -5.2694 & 0.8441 & -1.2609 & 1.3127 & A. vera, A. trigonantha & {$[92,93]$} \\
\hline 47 & $\begin{array}{c}4^{\prime}, 6^{\prime}-\mathrm{O}-\text { diacetate-7- } \\
\text { Hydroxyaloin A }\end{array}$ & -1.0169 & 1.1487 & -3.6664 & 1.1714 & A. succotrina & {$[73]$} \\
\hline
\end{tabular}


Table A1. Cont.

\begin{tabular}{|c|c|c|c|c|c|c|c|}
\hline \multirow{2}{*}{ No. } & \multirow{2}{*}{ Name of the Compound } & \multicolumn{2}{|c|}{$\begin{array}{l}\text { Main Protease } \\
\text { (PDB ID: 6LU7) }\end{array}$} & \multicolumn{2}{|c|}{$\begin{array}{l}\text { Spike Glycoprotein } \\
\text { ((PDB ID: 6M0J) }\end{array}$} & \multirow{2}{*}{ Plant Source } & \multirow{2}{*}{ Ref. } \\
\hline & & Score & RSMD & Score & RSMD & & \\
\hline \multicolumn{8}{|c|}{ I-Anthraquinones: } \\
\hline 48 & $\begin{array}{c}4^{\prime}, 6^{\prime}-\mathrm{O}-\text { diacetate-7- } \\
\text { Hydroxyaloin B }\end{array}$ & -5.9283 & 1.8131 & -3.8189 & 1.1443 & A. succotrina & [73] \\
\hline 49 & Aloinoside A & -5.5327 & 1.6795 & -7.3722 & 1.6129 & A. ferox, A. spp. & {$[92,94,95,107]$} \\
\hline 50 & Aloinoside B & -4.2386 & 2.0931 & -6.1225 & 0.9157 & A. vera, A. perryi & $\begin{array}{c}{[69,72,86,92,} \\
107,108]\end{array}$ \\
\hline 51 & Aloinoside C & -6.7035 & 1.3302 & -7.0975 & 1.2894 & A. spp. & [69] \\
\hline 52 & Homonataloside B & -7.4548 & 0.9307 & -7.0966 & 1.3986 & A. spp. & [109] \\
\hline 53 & Microdontin A & -5.3854 & 1.8687 & -3.0568 & 1.3618 & $\begin{array}{c}\text { A. gilbertii, A. microdonta, A. } \\
\text { calidophila, A. vera, A. perryi, A. } \\
\text { schelpei }\end{array}$ & {$[92,94-96,110]$} \\
\hline 54 & Microdontin B & -6.4459 & 1.4075 & -6.2021 & 1.4041 & $\begin{array}{l}\text { A. vera, A. perryi, } A \text {. } \\
\text { microdonta }\end{array}$ & {$[92,110]$} \\
\hline 55 & Microstigmin A & -6.2212 & 1.2076 & -6.7073 & 1.1774 & A. microstigma, A. broomii & [103] \\
\hline 56 & Desoxyaloin & -5.1323 & 1.4371 & -5.4503 & 1.1224 & A. spp. & [69] \\
\hline 57 & 8-O-Methoxy-7-hydroxyaloin B & -4.9067 & 1.2985 & -6.6635 & 1.4981 & A. vera, A. trigonantha & {$[92,93]$} \\
\hline 58 & 7-Hydroxyaloin B & -5.7138 & 1.6502 & -6.2245 & 0.5540 & $\begin{array}{l}\text { A. ghibensis, } A \text {. vera, } A \text {. } \\
\text { succotrina }\end{array}$ & {$[73,91]$} \\
\hline 59 & 6'-O-Acetyl-aloin B & -6.2829 & 1.1810 & -6.2769 & 1.2832 & A. vera, $A$. trigonantha & {$[93,111]$} \\
\hline 60 & 6'-O-Acetyl-aloin A & -7.0170 & 1.3290 & -6.7174 & 1.4200 & A. vera, $A$. trigonantha & {$[93,111]$} \\
\hline 61 & 6'-O-Acetyl-10-hydroxyaloin B & -5.4305 & 1.3206 & -5.1675 & 1.1849 & A. claviflora & [112] \\
\hline 62 & 10-Hydroxyaloin A & -5.5235 & 1.2517 & -5.3937 & 0.9974 & A. vera & {$[68,72,86,97]$} \\
\hline 63 & 10-Hydroxyaloin B & -4.5207 & 1.1644 & -6.2037 & 1.4416 & A. vera, A. littoralis & {$[68,72,97,113]$} \\
\hline 64 & Aloinoside D & -4.0281 & 1.5439 & -5.7067 & 1.6872 & A. $s p$. & [69] \\
\hline 65 & Deacetyllittoraloin & -5.4766 & 0.8960 & -3.2865 & 1.2900 & A. littoralis & [114] \\
\hline 66 & Littoraloin & -6.7095 & 1.9848 & -6.6415 & 1.4619 & A. littoralis & [114] \\
\hline 67 & Littoraloin & -5.4568 & 1.3628 & -1.6450 & 1.3238 & A. littoralis & [113] \\
\hline 68 & Deacetyllittoraloin & -4.6536 & 1.4897 & -3.4045 & 1.2748 & A. littoralis & {$[113]$} \\
\hline 69 & Littoraloside & -5.1344 & 1.6895 & -5.7699 & 1.5576 & A. littoralis & [114] \\
\hline 70 & $\begin{array}{l}\text { 6,8-Dihydroxy-4- } \\
\text { methylbenzanthrone }\end{array}$ & -4.8093 & 0.9928 & -3.6017 & 1.1112 & A. vera & [115] \\
\hline 71 & Anthrone; Enol-form & -3.7149 & 1.7269 & -3.3277 & 1.7661 & A. vera & {$[116]$} \\
\hline 72 & $\begin{array}{l}\text { 3,4-Dihydro-3,5,7-trihydroxy-9- } \\
\text { methyl-1 }(2 H) \text {-anthracenone }\end{array}$ & -5.3077 & 0.5534 & -5.5367 & 1.5708 & A. vera & [117] \\
\hline 73 & Aloesaponol II & -5.5596 & 0.9169 & -4.0884 & 1.1997 & A. saponaria & {$[78,80]$} \\
\hline 74 & Aloesaponol II-6-methyl ether & -5.4278 & 0.8931 & -5.6829 & 0.8923 & A. dawei & [66] \\
\hline 75 & Aloesaponol IV & -5.3144 & 1.0041 & -5.8792 & 1.2443 & A. saponaria & [79] \\
\hline 76 & Aloesaponol I & -6.2731 & 0.6260 & -5.5268 & 1.1253 & $\begin{array}{l}\text { A. megalacantha, A. dawei, } A \text {. } \\
\text { saponaria }\end{array}$ & {$[66,67,78,80]$} \\
\hline 77 & Aloesaponol III & -5.2375 & 1.6252 & -2.8273 & 0.5258 & A. saponaria & {$[79,80]$} \\
\hline 78 & 8-O-Methyl-aloesaponol III & -4.7557 & 2.6159 & -5.4051 & 0.7606 & A. saponaria & [79] \\
\hline 79 & $\begin{array}{c}\text { Aloesaponol } \\
\text { III-8-O- } \beta \text {-D-Glucopyranoside }\end{array}$ & -7.1900 & 0.9527 & -4.9331 & 1.1900 & A. saponaria & {$[79,80]$} \\
\hline 80 & $\begin{array}{c}\text { Aloesaponol } \\
\text { IV-8-O- } \beta \text {-D-Glucopyranoside }\end{array}$ & -6.4329 & 0.9875 & -6.1878 & 1.0722 & A. saponaria & [79] \\
\hline 81 & $\begin{array}{l}\text { O-de-Methylaloesaponol } \\
\text { IV-4-Epimer, } \\
\text { 4-O- } \beta \text {-D-glucopyranoside }\end{array}$ & -5.2621 & 1.6257 & -6.0435 & 1.6168 & A. vera & {$[118,119]$} \\
\hline
\end{tabular}


Table A1. Cont.

\begin{tabular}{|c|c|c|c|c|c|c|c|}
\hline \multirow{2}{*}{ No. } & \multirow{2}{*}{ Name of the Compound } & \multicolumn{2}{|c|}{$\begin{array}{l}\text { Main Protease } \\
\text { (PDB ID: 6LU7) }\end{array}$} & \multicolumn{2}{|c|}{$\begin{array}{l}\text { Spike Glycoprotein } \\
\text { ((PDB ID: 6M0J) }\end{array}$} & \multirow{2}{*}{ Plant Source } & \multirow{2}{*}{ Ref. } \\
\hline & & Score & RSMD & Score & RSMD & & \\
\hline \multicolumn{8}{|c|}{ I-Anthraquinones: } \\
\hline 82 & $\begin{array}{l}\text { Aloesaponol IV-4-Epimer, } \\
4-O-\beta \text {-D-glucopyranoside }\end{array}$ & -5.5878 & 1.4697 & -4.4875 & 1.2372 & A. vera & {$[118,119]$} \\
\hline 83 & Aloesaponol II-6-glucoside & -5.5097 & 1.6405 & -6.3430 & 1.7211 & A. saponaria & {$[78,80]$} \\
\hline 84 & $\begin{array}{l}\text { Aloesaponol } \\
\text { I-6-O- } \beta \text {-D-Glucoside }\end{array}$ & -6.4018 & 1.0686 & -6.4720 & 0.8722 & A. saponaria & {$[78,80]$} \\
\hline 85 & Prechrysophanol & -5.0097 & 1.3074 & -4.9503 & 0.9273 & A. graminicola & [120] \\
\hline 86 & Aloechrysone & -5.5183 & 1.0812 & -5.2203 & 1.1941 & A. berhana & [121] \\
\hline \multicolumn{8}{|c|}{ II-Chromones: } \\
\hline 87 & $\begin{array}{l}\text { 2,7-Dihydroxy-5- } \\
\text { methylchromone }\end{array}$ & -4.1044 & 1.5749 & -4.3380 & 2.1225 & A. arborescens & [122] \\
\hline 88 & Altechromone A & -4.3964 & 1.3753 & -4.0177 & 2.5253 & A. vera, A. ferox & {$[76]$} \\
\hline 89 & $\begin{array}{l}\text { 7-Hydroxy-5-(hydroxymethyl)- } \\
\text { 2-methylchromone }\end{array}$ & -4.6654 & 1.0133 & -4.0034 & 1.0116 & A. vera, A. spp. & {$[68,69,123]$} \\
\hline 90 & $\begin{array}{l}\text { 5-(Hydroxymethyl)-7-methoxy- } \\
\text { 2-methylchromone }\end{array}$ & -5.0942 & 1.7087 & -4.3604 & 0.6077 & A. vera & [68] \\
\hline 91 & Aloesone & -5.3434 & 0.8671 & -4.4459 & 1.6654 & A. spp. & [124] \\
\hline 92 & Aloesol & -5.4824 & 1.1217 & -4.5119 & 1.3491 & A. spp. & [124] \\
\hline 93 & Saikochromone A & -4.0246 & 1.1592 & -4.6675 & 0.8802 & A. vera & {$[68]$} \\
\hline 94 & $\begin{array}{l}\text { 2-Carboxyethenyl-5,7- } \\
\text { dihydroxychromone }\end{array}$ & -5.4560 & 0.8633 & -4.3033 & 1.4776 & A. cremnophila & [125] \\
\hline 95 & $\begin{array}{l}\text { 5-((4E)-2'-Oxopentenyl)-2- } \\
\text { hydroxymethylchromone }\end{array}$ & -5.2408 & 1.2458 & -4.6543 & 0.9525 & A. vera & [68] \\
\hline 96 & $\begin{array}{l}\text { 2-Acetonyl-7-hydroxy-8-(3- } \\
\text { hydroxyacetonyl)-5- } \\
\text { methylchromone }\end{array}$ & -6.1295 & 1.1673 & -5.6294 & 0.8828 & A. ferox & [126] \\
\hline 97 & $\begin{array}{c}5-\left((S)-2^{\prime}-\mathrm{O} x \mathrm{-}-4^{\prime}-\right. \\
\text { hydroxypentyl)-2- } \\
\text { hydroxymethylchromone }\end{array}$ & -5.6533 & 0.8672 & -4.5742 & 1.0536 & A. spp., A. vera & {$[68,69,123]$} \\
\hline 98 & 7-O-methyl-(R)-aloesinol & -5.7749 & 1.3751 & -6.3349 & 1.0728 & 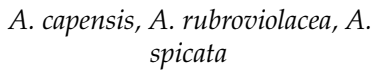 & $\begin{array}{c}{[69,123,127,} \\
128]\end{array}$ \\
\hline 99 & 7-O-methyl-(S)-aloesinol & -4.9862 & 1.0634 & -6.5826 & 1.3861 & A. vera & [129-131] \\
\hline 100 & Aloesinol; $\left(2^{\prime} S\right)$-form & -6.5412 & 1.3314 & -5.9231 & 0.9830 & A. vera & [129-131] \\
\hline 101 & $\begin{array}{l}\text { 8-C-Glucosyl-7-O- } \\
\text { methylaloediol }\end{array}$ & -6.5616 & 1.4702 & -6.1983 & 1.3370 & A. vera & [130-132] \\
\hline 102 & C-2'-Decoumaroyl-aloeresin G & -6.3203 & 2.2082 & -5.6674 & 0.6253 & A. vera, A. spp. & {$[69,123,132]$} \\
\hline 103 & Deacetylaloesin & -5.4580 & 1.4439 & -5.6769 & 0.7237 & A. vera var. chinensis & {$[133]$} \\
\hline 104 & Isobiflorin & -4.3917 & 1.0141 & -5.5361 & 1.3146 & A. vera & {$[131]$} \\
\hline 105 & 8-C-Glucosyl-noreugenin & -6.0155 & 0.9498 & -5.3311 & 1.2871 & A. vera & {$[132]$} \\
\hline 106 & Neoaloesin A & -4.1314 & 1.4402 & -5.3727 & 1.2553 & A. vera & {$[132,134]$} \\
\hline 107 & Aloesin (Aloeresin B) & -5.1920 & 1.4721 & -6.0011 & 0.9641 & $\begin{array}{c}\text { A. vera, } A \text {. monticola, } A . \\
\text { trigonantha } A \text {. saponaria, } A \text {. } \\
\text { arborescens }\end{array}$ & $\begin{array}{c}{[68,92,93,132,} \\
135-137]\end{array}$ \\
\hline 108 & 7-O-Methylaloesin & -6.5211 & 1.0562 & -4.7873 & 0.7405 & A. vera, A. rupestris & {$[92,105]$} \\
\hline 109 & $\begin{array}{l}\text { 2-Acetonyl-8-(2-furoylmethyl)- } \\
\text { 7-hydroxy-5-methylchromone }\end{array}$ & -5.5785 & 1.2539 & -5.9486 & 1.4100 & A. ferox & {$[126]$} \\
\hline 110 & 8-C-Glucosyl-(R)-aloesol & -6.9810 & 1.2199 & -6.5885 & 1.2379 & A. vera & {$[68,92,132,136]$} \\
\hline 111 & 8-C-Glucosyl-(S)-aloesol & -5.9979 & 1.2224 & -3.0178 & 1.2511 & A. vera & [132] \\
\hline 112 & $\begin{array}{l}\text { 8-C-Glucosyl-7-methoxy-(R)- } \\
\text { aloesol }\end{array}$ & -6.9122 & 1.5762 & -5.2251 & 0.8301 & A. vera & [132] \\
\hline 113 & $\begin{array}{l}\text { 8-C-Glucosyl-7-methoxy-(S)- } \\
\text { aloesol }\end{array}$ & -6.2867 & 1.2856 & -4.9903 & 0.9918 & A. vera & {$[68,132,136]$} \\
\hline
\end{tabular}


Table A1. Cont.

\begin{tabular}{|c|c|c|c|c|c|c|c|}
\hline \multirow{2}{*}{ No. } & \multirow{2}{*}{ Name of the Compound } & \multicolumn{2}{|c|}{$\begin{array}{l}\text { Main Protease } \\
\text { (PDB ID: 6LU7) }\end{array}$} & \multicolumn{2}{|c|}{$\begin{array}{l}\text { Spike Glycoprotein } \\
\text { ((PDB ID: 6M0J) }\end{array}$} & \multirow{2}{*}{ Plant Source } & \multirow{2}{*}{ Ref. } \\
\hline & & Score & RSMD & Score & RSMD & & \\
\hline \multicolumn{8}{|c|}{ I-Anthraquinones: } \\
\hline 114 & $\begin{array}{l}\text { 2"-O-p-Coumaroyl-(S)- } \\
\text { aloesinol }\end{array}$ & -6.4949 & 1.1099 & -6.3880 & 1.7012 & A. nobilis & [138] \\
\hline 115 & $\begin{array}{l}\text { 2"-O-(4-methoxycinnamoyl)- } \\
\text { (S)-aloesinol }\end{array}$ & -6.8222 & 0.9924 & -8.0574 & 1.4996 & A. nobilis & [104] \\
\hline 116 & $\begin{array}{l}\text { 2"-O-Cinnamoyl-8-C-glucosyl- } \\
\text { 7-O-methyl-aloediol A }\end{array}$ & -6.9842 & 0.9200 & -7.4491 & 1.1903 & A. vera & [131] \\
\hline 117 & 4"-Deoxyaloeresin D & -1.9659 & 1.4660 & -7.3969 & 1.4416 & A. vera & [139] \\
\hline 118 & Aloeresin D & -7.3865 & 1.5512 & -6.6808 & 1.3432 & A. ferox, A. vera & $\begin{array}{c}69,123,132, \\
140,141]\end{array}$ \\
\hline 119 & Isoaloeresin D & -5.8280 & 1.4838 & -7.5561 & 1.2248 & A. vera & $\begin{array}{c}68,92,129- \\
132,136]\end{array}$ \\
\hline 120 & Rabaichromone & -7.3914 & 1.9603 & -7.8715 & 1.1703 & A. rabaiensis, A. vera & {$[132,142]$} \\
\hline 121 & Isorabaichromone & -7.5470 & 1.4108 & -7.2656 & 1.4428 & A. vera & [129-132] \\
\hline 122 & Aloeresin J & -6.9723 & 1.9908 & -6.4352 & 1.4979 & A. vera & [132] \\
\hline 123 & $\begin{array}{l}\text { 8-[C- } \beta \text {-D-[2-O-(E)-cinnamoyl] } \\
\text { glucopyranosyl]-2-[(R)-2- } \\
\text { hydroxypropyl]7-methoxy-5- } \\
\text { methylchromone }\end{array}$ & -7.3516 & 0.9022 & -5.8935 & 1.2315 & A. vera & [132] \\
\hline 124 & Aloeresin K & -6.2857 & 1.5121 & -6.9020 & 1.8499 & A. vera & {$[111,132]$} \\
\hline 125 & Aloeresin F & -7.5814 & 1.9617 & -6.6320 & 1.4268 & A. peglerae & {$[143,144]$} \\
\hline 126 & $\begin{array}{l}2 " \text {-O-E-cinnamoyl-2'-Ketone } \\
\left(2^{\prime} R\right) \text { aloesinol-7-methyl ether }\end{array}$ & -6.5227 & 1.6510 & -5.7926 & 1.2582 & A. broomii & [145] \\
\hline 127 & 7-O-Methylaloeresin A & -7.3061 & 1.1520 & -6.8482 & 0.9873 & A. vera, A. perryi, A. marlothii & {$[92,105,132]$} \\
\hline 128 & Aloeresin A & -7.0228 & 1.1297 & -6.1730 & 1.3563 & $\begin{array}{l}\text { A. cremnophila, A. jacksonii, A. } \\
\text { arborescens, A. vera }\end{array}$ & {$[92,132,146]$} \\
\hline 129 & Isoaloeresin $\mathrm{A}$ & -7.0698 & 1.8469 & -6.9601 & 1.6099 & A. ferox & [147] \\
\hline 130 & 6"-O-p-Coumaroylaloesin & -6.1054 & 1.3654 & -5.5547 & 1.4791 & A. vera, A. castanea & {$[143,144]$} \\
\hline 131 & Aloeribide & -6.5988 & 1.1683 & -8.0886 & 1.1338 & A. vera, A. monticola & [86] \\
\hline 132 & $\begin{array}{l}\text { 2"-O-(3,4-dihydroxy-E- } \\
\text { cinnamoyl) 2'-Ketone, }\left(2^{\prime} R\right) \\
\text { Aloesinol-7-methyl ether }\end{array}$ & -7.6830 & 1.3783 & -5.1857 & 0.8784 & A. broomii & [145] \\
\hline 133 & 2"-O-Feruloylaloesin & -6.3246 & 1.4172 & -7.3571 & 1.3775 & A. arborescens & [148] \\
\hline 134 & $\begin{array}{l}\text { 2"-O-(4-hydroxy-3-methoxy- } E- \\
\text { cinnamoyl) 2'-Ketone, } \\
\left(2^{\prime} R\right) \text {-aloesinol-7-methyl ether }\end{array}$ & -7.9510 & 1.7236 & -6.5096 & 1.2159 & A. africana & [145] \\
\hline 135 & $\begin{array}{l}\text { 2"-O-tigloyl-2'-Ketone, } \\
\left(2^{\prime} R\right) \text {-aloesinol }\end{array}$ & -7.0060 & 1.0927 & -1.4865 & 1.2366 & A. cremnophila, A. jacksonii & [125] \\
\hline 136 & $\begin{array}{l}\text { 2",6"-bis-O-(4-hydroxy- } E \text { - } \\
\text { cinnamoyl) 2'-Ketone, } \\
\left(2^{\prime} R\right) \text {-aloesinol }\end{array}$ & -7.6466 & 1.6059 & -6.8589 & 2.8077 & A. speciosa & [145] \\
\hline 137 & Aloeresin E & -6.8483 & 1.7166 & -3.3935 & 1.5214 & A. peglerae & {$[143,144]$} \\
\hline 138 & Aloeresin C & -3.1926 & 1.4036 & 4.6545 & 1.2671 & A. spp. & {$[140,141]$} \\
\hline 139 & $\begin{array}{c}\text { trans- } p \text {-coumaroyl-4'-O- } \\
\text { Glucosyl-isoaloeresin } \\
\text { D-I a }\end{array}$ & -7.3070 & 1.8254 & -5.2510 & 1.8902 & A. vera & [129-132] \\
\hline 140 & $\begin{array}{l}\text { cis-p-coumaroyl- } 4^{\prime}-\mathrm{O}- \\
\text { Glucosylisoaloeresin } \\
\text { D-II a }\end{array}$ & -5.1214 & 1.9414 & -6.9804 & 1.5954 & A. vera & [129-132] \\
\hline
\end{tabular}


Table A1. Cont.

\begin{tabular}{|c|c|c|c|c|c|c|c|}
\hline \multirow{2}{*}{ No. } & \multirow{2}{*}{ Name of the Compound } & \multicolumn{2}{|c|}{$\begin{array}{l}\text { Main Protease } \\
\text { (PDB ID: 6LU7) }\end{array}$} & \multicolumn{2}{|c|}{$\begin{array}{l}\text { Spike Glycoprotein } \\
\text { ((PDB ID: 6M0J) }\end{array}$} & \multirow{2}{*}{ Plant Source } & \multirow{2}{*}{ Ref. } \\
\hline & & Score & RSMD & Score & RSMD & & \\
\hline \multicolumn{8}{|c|}{ I-Anthraquinones: } \\
\hline 141 & $\begin{array}{l}\text { 8-C-(2'-O-coumaroylglucosyl)- } \\
\text { 7-hydroxy-5-methyl-chromone- } \\
\text { 2-carboxylic acid }\end{array}$ & -7.0093 & 1.2428 & -3.8621 & 1.2324 & A. vera, A. perryi & [92] \\
\hline 142 & $\begin{array}{c}\text { 9-Dihydroxyl-2'-O-(Z)- } \\
\text { cinnamoyl-7-methoxy-aloesin }\end{array}$ & -7.6616 & 1.3432 & -6.5510 & 1.0865 & A. vera & [132] \\
\hline 143 & $\begin{array}{c}\text { 5-((S)-2'-Oxo-4'- } \\
\text { hydroxypentyl)-2-( } \beta \text {-D- } \\
\text { glucopyranosyloxy-methyl) } \\
\text { chromone }\end{array}$ & -6.3604 & 1.6246 & -5.6622 & 0.9999 & A. vera & {$[68,123]$} \\
\hline 144 & $\begin{array}{l}\text { 8-Glucosyl-(2'-O-cinnamoyl)-7- } \\
\text { O-methyl-aloediol A }\end{array}$ & -6.8459 & 1.3641 & -6.1606 & 1.1397 & A. vera & [132] \\
\hline 145 & Aloeresin G & -5.6136 & 1.0175 & -7.2021 & 1.2832 & A. vera & {$[69,123,149]$} \\
\hline 146 & Aloeresin $\mathrm{H}$ & -7.5738 & 1.6723 & -7.5525 & 1.2922 & A. ferox & [150] \\
\hline 147 & Aloeresin I & -7.4396 & 2.2729 & -7.4337 & 1.7717 & A. ferox & [151] \\
\hline 148 & Iso-aloesin & -6.5817 & 0.9104 & -5.3266 & 1.3373 & A. vera var. chinensis & [152] \\
\hline 149 & Aloeveraside B & -7.0658 & 1.3476 & -5.6113 & 1.4352 & A. vera & {$[72,132]$} \\
\hline 150 & Aloeveraside A & -7.1344 & 1.1636 & -4.8353 & 1.2241 & A. vera & {$[72,132]$} \\
\hline 151 & Furoaloesone & -5.2765 & 1.3977 & -5.3016 & 1.0583 & A. ferox & [153] \\
\hline \multicolumn{8}{|c|}{ III-Coumarins: } \\
\hline 152 & Coumarin & -4.3565 & 1.3443 & -3.5142 & 0.7049 & A. vera & [86] \\
\hline 153 & 7-Demethylsiderin & -4.4857 & 1.2535 & -4.6641 & 1.3044 & A. vera, A. megalacantha & {$[72,86]$} \\
\hline \multicolumn{8}{|c|}{ IV-Flavonoids: } \\
\hline 154 & Apigenin & -4.8832 & 1.1056 & -4.9431 & 1.4340 & A. vera & [154] \\
\hline 155 & Kaempferol & -5.5622 & 0.6388 & -5.2731 & 1.3518 & A. vera & [154] \\
\hline 156 & Quercetin & -5.5045 & 0.8816 & -5.0091 & 1.3859 & A. vera & [154] \\
\hline 157 & Myricetin & -4.3458 & 1.1650 & -5.1872 & 1.7167 & A. vera & [154] \\
\hline 158 & Quercitrin & -5.9830 & 1.1253 & -6.6787 & 1.2189 & A. vera & [154] \\
\hline 159 & Rutin & -7.7285 & 1.4051 & -6.5175 & 1.7434 & A. vera & [154] \\
\hline 160 & $\begin{array}{c}3^{\prime}, 5^{\prime}, 6,7-\text { Tetra-methyl ether, } \\
5-O-[\alpha \text {-L-rhamnopyranosyl- } \\
(1 \rightarrow 6)-\beta \text {-D-galactopyranoside }] \\
3^{\prime}, 4^{\prime}, 5,5^{\prime}, 6,7- \\
\text { Hexahydroxyflavone }\end{array}$ & -6.4680 & 1.4828 & -7.2475 & 1.4030 & A. vera & [155] \\
\hline 161 & Catechin & -5.5232 & 0.7426 & -5.0722 & 0.8989 & A. vera & [154] \\
\hline 162 & Epicatechin & -5.3431 & 1.3310 & -5.0829 & 1.3469 & A. vera & [154] \\
\hline 163 & $\begin{array}{c}3^{\prime}, 4^{\prime}, 6 \text {-Tri-Me ether, } \\
5-O-[\alpha \text {-L-rhamnopyranosyl- } \\
(1 \rightarrow 6)-\beta \text {-D-glucopyranoside] } \\
3^{\prime}, 4^{\prime}, 5,6,7- \\
\text { Pentahydroxyisoflavone }\end{array}$ & 0.3390 & 0.9914 & -4.0257 & 1.8089 & A. vera & [156] \\
\hline \multicolumn{8}{|c|}{$\begin{array}{l}\text { V-Phenolic Compounds: } \\
\text { a-Simple phenolic compounds: }\end{array}$} \\
\hline 164 & Pyrocatechol & -3.9037 & 0.5358 & -3.1988 & 1.0732 & A. ferox & [157] \\
\hline 165 & Salicylaldehyde & -2.6754 & 1.0693 & -3.2178 & 1.2797 & A. vera & {$[72,86]$} \\
\hline 166 & $p$-Cresol & -3.7780 & 1.1628 & -3.5110 & 1.1472 & A. vera & {$[72,86]$} \\
\hline 167 & $p$-Hydroxyacetophenone & -4.0224 & 1.8629 & -3.7773 & 0.7970 & A. ferox & [157] \\
\hline
\end{tabular}


Table A1. Cont.

\begin{tabular}{|c|c|c|c|c|c|c|c|}
\hline \multirow{2}{*}{ No. } & \multirow[t]{2}{*}{ Name of the Compound } & \multicolumn{2}{|c|}{$\begin{array}{l}\text { Main Protease } \\
\text { (PDB ID: 6LU7) }\end{array}$} & \multicolumn{2}{|c|}{$\begin{array}{l}\text { Spike Glycoprotein } \\
\text { ((PDB ID: 6M0J) }\end{array}$} & \multirow{2}{*}{ Plant Source } & \multirow{2}{*}{ Ref. } \\
\hline & & Score & RSMD & Score & RSMD & & \\
\hline \multicolumn{8}{|c|}{ I-Anthraquinones: } \\
\hline 168 & $p$-Hydroxybenzaldehyde & -3.1097 & 0.7939 & -3.5440 & 1.5859 & A. ferox & [157] \\
\hline 169 & p-Anisaldehyde & -3.9164 & 1.3669 & -3.4465 & 1.1778 & A. vera & {$[72,86]$} \\
\hline 170 & Phloretic acid & -4.3823 & 1.2905 & -4.1107 & 1.0512 & A. vera & {$[72,86]$} \\
\hline 171 & $\begin{array}{l}\text { Methyl-3-(4-hydroxyphenyl) } \\
\text { propionate }\end{array}$ & -4.7496 & 0.8674 & -3.9136 & 0.9518 & A. vera & {$[72,86]$} \\
\hline 172 & Coumaric acid & -4.5055 & 1.4107 & -3.6587 & 1.1690 & A. vera & [154] \\
\hline 173 & Caffeic acid & -4.1969 & 1.2736 & -3.8859 & 1.0162 & A. vera & [154] \\
\hline 174 & Ferulic acid & -4.3845 & 0.9040 & -4.4689 & 1.0173 & A. vera & [154] \\
\hline 175 & Sinapic acid & -5.1021 & 1.0097 & -4.2763 & 1.1207 & A. vera & [154] \\
\hline 176 & Orcinol & -3.9362 & 1.2430 & -3.7654 & 1.4027 & A. $s p$. & [69] \\
\hline 177 & Gentisic acid & -3.8595 & 1.6010 & -3.9828 & 1.3232 & A. vera & [154] \\
\hline 178 & Protocatechuic acid & -3.6447 & 1.5645 & -4.1049 & 1.3881 & A. vera & [154] \\
\hline 179 & Vanillic acid & -4.0256 & 1.0470 & -4.0827 & 0.9452 & A. vera & [154] \\
\hline 180 & Gallic acid & -4.1961 & 0.5757 & -3.5679 & 0.8059 & A. vera & [154] \\
\hline 181 & Syringic acid & -4.1467 & 1.2874 & -4.6308 & 1.2947 & A. vera & [154] \\
\hline 182 & $\begin{array}{l}\text { 1-(2,4-Dihydroxy-6- } \\
\text { methylphenyl) } \\
\text { ethanone }\end{array}$ & -3.8183 & 1.3698 & -3.9336 & 0.9642 & A. vera & [72] \\
\hline \multicolumn{8}{|c|}{ b-Phenyl-Pyran and Phenyl-pyrone derivatives: } \\
\hline 183 & Aloenin aglycone. & -4.8494 & 1.2878 & -3.8957 & 1.3574 & A. vera, A. spp. & $\begin{array}{c}{[68,69,123,158,} \\
159]\end{array}$ \\
\hline 184 & $\begin{array}{l}\text { 6-(2,4-Dihydroxy-6- } \\
\text { pentylphenyl)-4-hydroxy-2H- } \\
\text { pyran-2-one }\end{array}$ & -3.1749 & 1.0339 & -5.5428 & 1.0487 & A. arborescens & [160] \\
\hline 185 & $\begin{array}{c}\text { 6-[[2,4-Dihydroxy-6-[2-(4- } \\
\text { hydroxyphenyl) } \\
\text { ethenyl]-4-hydroxy-2H-pyran- } \\
\text { 2-one }\end{array}$ & -5.9742 & 1.4002 & -5.8852 & 1.4624 & A. arborescens & [160] \\
\hline 186 & Aloenin A & -5.3723 & 1.3544 & -4.5645 & 1.5586 & A. vera, A. arborescens & {$[85,92,123,159]$} \\
\hline 187 & $\begin{array}{l}2 " \text {-O-trans- } p \text {-coumaroyl- } \\
\text { aloenin }\end{array}$ & -7.0328 & 1.6452 & -6.1026 & 1.2183 & A. vera, A. nyeriensis, A. spicata & [159] \\
\hline 188 & 4",6"-Ethylidenealoenin & -6.3221 & 2.1206 & -6.8580 & 1.0640 & A. arborescens, A. hijazensis & [82] \\
\hline 189 & Aloenin C & -4.0535 & 1.3070 & -4.7701 & 1.7252 & A. $s p$. & [123] \\
\hline 190 & $\begin{array}{l}\text { 10-O- } \beta \text {-D-glucopyranosyl- } \\
\text { aloenin }\end{array}$ & -6.1378 & 1.0013 & -6.6976 & 1.3721 & A. sp., A. vera, A. spicata & {$[127,136]$} \\
\hline 191 & Aloenin B & -7.0573 & 1.9426 & -4.7766 & 1.3631 & A. hijazensis, A. spicata, A. vera & $\begin{array}{c}{[68,69,82,123,} \\
136]\end{array}$ \\
\hline 192 & $\begin{array}{l}\text { 2,4-Dihydroxy- } \beta \text {-(4- } \\
\text { hydroxyphenyl)-5-(4-methoxy- } \\
\text { 2-oxo-2H-pyran-6-yl)-6- } \\
\text { methylbenzenepropanoic acid; } \\
\text { Et ester }\end{array}$ & -6.0558 & 1.2415 & -6.5747 & 1.4078 & A. vera & [161] \\
\hline 193 & $\begin{array}{c}\text { 6-[[3,5-Dihydroxy-2-(1- } \\
\text { oxohexyl) phenyl] } \\
\text { methyl]-4-hydroxy-2H-pyran- } \\
\text { 2-one }\end{array}$ & -5.5175 & 1.3328 & -5.1989 & 1.4473 & A. arborescens & [160] \\
\hline 194 & $\begin{array}{l}\text { 6-[[3,5-Dihydroxy-2-[3-(4- } \\
\text { hydroxyphenyl)-1-oxo-2- } \\
\text { propenyl] phenyl] } \\
\text { methyl]-4-hydroxy-2H-pyran- } \\
\text { 2-one }\end{array}$ & -3.9537 & 1.4667 & -6.8047 & 1.2550 & A. arborescens & [160] \\
\hline
\end{tabular}


Table A1. Cont.

\begin{tabular}{|c|c|c|c|c|c|c|c|}
\hline \multirow{2}{*}{ No. } & \multirow{2}{*}{ Name of the Compound } & \multicolumn{2}{|c|}{$\begin{array}{l}\text { Main Protease } \\
\text { (PDB ID: 6LU7) }\end{array}$} & \multicolumn{2}{|c|}{$\begin{array}{l}\text { Spike Glycoprotein } \\
\text { ((PDB ID: 6M0J) }\end{array}$} & \multirow{2}{*}{ Plant Source } & \multirow{2}{*}{ Ref. } \\
\hline & & Score & RSMD & Score & RSMD & & \\
\hline \multicolumn{8}{|c|}{ I-Anthraquinones: } \\
\hline 195 & $\begin{array}{l}\text { 3,4-Dihydro-7-hydroxy-4-(4- } \\
\text { hydroxyphenyl)-6-(4-methoxy- } \\
\text { 2-oxo-2H-pyran-6-yl)-5-methyl- } \\
\text { 2H-1-benzopyran-2-one }\end{array}$ & -6.0022 & 1.3606 & -6.4475 & 1.1932 & A. vera & [161] \\
\hline 196 & Feralolide & -5.7980 & 1.8453 & -5.4781 & 1.4521 & A. arborescent, $A$. ferox, $A$. vera & $\begin{array}{c}{[70,82,86,162,} \\
163]\end{array}$ \\
\hline 197 & 5'-O-Methylferalolide & -6.3808 & 1.3485 & -5.9990 & 1.3806 & A. vera & {$[164]$} \\
\hline 198 & $\begin{array}{l}\text { Feralolide- } 3^{\prime}-O-\beta \text {-D- } \\
\text { Glucopyranoside }\end{array}$ & -5.6364 & 1.3200 & -4.3041 & 2.3081 & A. arborescens, $A$. vera & {$[70,165]$} \\
\hline 199 & $\begin{array}{l}\text { 3,3'-Bi(3,4-dihydro-6-methoxy- } \\
\text { 2H-1-benzopyran-4-ol). } \\
\text { 3,3'-Bi(3,4-dihydro-4-hydroxy- } \\
\text { 6-methoxy-2H-1-benzopyran) }\end{array}$ & -5.3093 & 1.7270 & -5.2061 & 1.4071 & A. vera & [166] \\
\hline \multicolumn{8}{|c|}{ c-Benzofurans: } \\
\hline 200 & $\begin{array}{l}\text { 5-Hydroxy-3- } \\
\text { methylnaphtho[2,3-c] } \\
\text { furan-4(1H)-one }\end{array}$ & -4.3383 & 1.1118 & -4.0958 & 0.7359 & A. ferox & {$[71]$} \\
\hline 201 & $\begin{array}{l}\text { 5-Hydroxy-3- } \\
\text { methylnaphtho[2,3-c] } \\
\text { furan-4(9H)-one }\end{array}$ & -4.1346 & 1.3867 & -4.0957 & 0.7362 & A. ferox & {$[71]$} \\
\hline 202 & Isoeleutherol & -4.7544 & 1.2527 & -4.5232 & 0.7749 & A. graminicola & [167] \\
\hline 203 & Isoeleutherol glucoside & -6.0044 & 1.3381 & -4.6325 & 1.4751 & A. saponaria & [80] \\
\hline 204 & $\begin{array}{l}\text { 8-Hydroxy-1- } \\
\text { methylnaphtho[2,3-c] } \\
\text { furan-4,9-dione }\end{array}$ & -5.0447 & 1.3119 & -4.3271 & 0.8506 & A. ferox & {$[71]$} \\
\hline \multicolumn{8}{|c|}{ d-Naphthalin derivatives: } \\
\hline 205 & Droserone & -4.5525 & 1.0154 & -4.1450 & 1.1420 & A. dawei & [66] \\
\hline 206 & Droserone-5-methyl ether & -4.8881 & 1.1213 & -4.2859 & 1.2524 & A. dawei & {$[66]$} \\
\hline 207 & Hydroxydroserone & -4.9712 & 1.0739 & -3.7656 & 1.9742 & A. dawei & {$[66]$} \\
\hline 208 & Ancistroquinone $\mathrm{C}$ & -4.8894 & 1.4452 & -4.2108 & 0.5425 & A. dawei & {$[66]$} \\
\hline 209 & $\begin{array}{l}\text { 5,8-Dihydroxy-3-methoxy-2- } \\
\text { methyl-1,4-naphthoquinone }\end{array}$ & -5.0591 & 1.0203 & -3.5906 & 0.8949 & A. dawei & [66] \\
\hline 210 & Malvone A & -4.7003 & 0.6291 & -4.7158 & 1.0717 & A. dawei & {$[66]$} \\
\hline 211 & $\begin{array}{l}\text { 6-Hydroxy-3,5-dimethoxy-2- } \\
\text { methyl-1,4-naphthoquinone }\end{array}$ & -4.8603 & 1.1151 & -4.2108 & 1.2529 & A. dawei & [66] \\
\hline 212 & 1,8-Dimethoxynepodinol & -4.8625 & 1.0642 & -4.1478 & 0.9217 & A. megalacantha & {$[67]$} \\
\hline 213 & $\begin{array}{l}\text { 3-Hydroxy-1-(1,7-dihydroxy- } \\
\text { 3,6-dimethoxynaphthalen-2-yl) } \\
\text { propan-1-one }\end{array}$ & -5.8504 & 0.7746 & -5.2376 & 1.0515 & A. vera & [168] \\
\hline 214 & Plicataloside & -3.4118 & 1.4389 & -5.6793 & 1.2349 & A. plicatilis & [169] \\
\hline 215 & Kenyaloside & -7.2910 & 1.6098 & -4.6954 & 1.3254 & a Kenyan A. spp. & [170] \\
\hline 216 & Aloveroside A & -7.5802 & 1.8561 & -6.8612 & 1.5133 & A. vera, A. spp. & {$[69,123,171]$} \\
\hline 217 & Isoeleutherin & -4.3217 & 1.3635 & -3.7234 & 0.6554 & A. graminicola & {$[167]$} \\
\hline 218 & $\begin{array}{c}\text { 1-(4-Hydroxyphenyl)-6,9- } \\
\text { dihydroxy-7-methyl-8-acetyl- } \\
\text { 1,2-dihydro-(3H)-naphtho[2,1- } \\
\text { b] } \\
\text { pyran-3-one }\end{array}$ & -3.8117 & 1.5671 & -6.9288 & 0.9758 & A. ferox & [172] \\
\hline \multicolumn{8}{|c|}{ VI-Alkaloids: } \\
\hline 219 & 4,7-Dichloroquinoline & -1.6976 & 0.2458 & -3.5415 & 1.2153 & A. hijazensis & [82] \\
\hline 220 & N, N-Dimethyl-(+)-coniine & -1.9420 & 0.6273 & -1.7066 & 1.3831 & A. sabaea & {$[173]$} \\
\hline
\end{tabular}


Table A1. Cont.

\begin{tabular}{|c|c|c|c|c|c|c|c|}
\hline \multirow{2}{*}{ No. } & \multirow{2}{*}{ Name of the Compound } & \multicolumn{2}{|c|}{$\begin{array}{l}\text { Main Protease } \\
\text { (PDB ID: 6LU7) }\end{array}$} & \multicolumn{2}{|c|}{$\begin{array}{l}\text { Spike Glycoprotein } \\
\text { ((PDB ID: 6M0J) }\end{array}$} & \multirow{2}{*}{ Plant Source } & \multirow{2}{*}{ Ref. } \\
\hline & & Score & RSMD & Score & RSMD & & \\
\hline \multicolumn{8}{|c|}{ I-Anthraquinones: } \\
\hline 221 & $\gamma$-Coniceine & -4.2358 & 0.9461 & -3.6823 & 0.9519 & A. $s p$. & {$[173,174]$} \\
\hline \multicolumn{8}{|c|}{ VII-Fatty acid derivatives: } \\
\hline 222 & 10-Hydroxyoctadecanoic acid & -6.1427 & 1.4991 & -4.4657 & 1.1518 & A. ferox & {$[157]$} \\
\hline 223 & 10-Oxooctadecanoic acid & -6.3362 & 1.0628 & -5.8079 & 1.1759 & A. ferox & {$[157]$} \\
\hline 224 & $\begin{array}{l}\text { Methyl-26-O-feruloyl- } \\
\text { oxyhexacosanate }\end{array}$ & -7.6053 & 1.7939 & -7.2349 & 1.2702 & A. megalacantha & {$[67]$} \\
\hline \multicolumn{8}{|c|}{ VIII-Miscellaneous compounds: } \\
\hline 225 & Nilic acid & -4.0096 & 0.9979 & -2.3951 & 0.6370 & A. littoralis & {$[113]$} \\
\hline 226 & $N$-(4-Chlorobutyl) butanamide & -4.7596 & 0.6115 & -3.9758 & 0.9418 & A. sabaea & {$[173]$} \\
\hline 227 & 3-Furanmethanol & -3.9177 & 0.9518 & -3.4939 & 0.7289 & A. arborescens & {$[175]$} \\
\hline 228 & $\begin{array}{l}\text { 3, 6-Dioxo-3, 3a, 6, } 6 \\
\text { a-tetrahydropyrrolo }[3,4 \text {-c] } \\
\text { pyrrole-1, 4-dicarboxamide }\end{array}$ & -4.1012 & 1.7165 & -3.8036 & 1.0232 & A. vera & {$[176]$} \\
\hline 229 & $\begin{array}{l}\text { 1-(2,4-Dihydroxy-6- } \\
\text { methylphenyl)-1-(4- } \\
\text { hydroxyphenyl) } \\
\text { ethane }\end{array}$ & -4.7735 & 2.0838 & -2.0969 & 1.0198 & A. ferox & [177] \\
\hline 230 & Chlorogenic acid & -4.1722 & 1.3907 & -5.6761 & 1.2173 & A. vera, A. arborescens & {$[154]$} \\
\hline 231 & Pluridone; $(E)$-form & -4.9712 & 1.2855 & -3.8181 & 1.0980 & A. pluridens & {$[178]$} \\
\hline 232 & Feroxidin & -4.3149 & 1.0601 & -3.9958 & 1.0673 & A. ferox, A. arborescens & $\begin{array}{l}{[69,70,72,86,} \\
123,179,180]\end{array}$ \\
\hline 233 & Feroxin A & -5.5313 & 1.4467 & -5.2869 & 1.0687 & A. spp. & [181] \\
\hline 234 & Feroxin B & -6.6446 & 2.1091 & -6.2902 & 1.7466 & A. spp. & {$[181]$} \\
\hline 235 & Veracylglucan A & -5.7829 & 1.2199 & -4.7653 & 0.8308 & A. vera & {$[182]$} \\
\hline 236 & Veracylglucan B & -3.0836 & 1.0444 & -1.0368 & 1.0780 & A. vera & {$[182]$} \\
\hline 237 & Veracylglucan C & -6.3433 & 2.2092 & -7.2512 & 1.9263 & A. vera & [182] \\
\hline
\end{tabular}

\section{References}

1. EI Zowalaty, M.E.; Young, S.G.; Järhult, J.D. Environmental impact of the COVID-19 pandemic-a lesson for the future. Infect. Ecol. Epidemiol. 2020, 10, 1768023. [CrossRef]

2. El Zowalaty, M.E.; Järhult, J.D. From SARS to COVID-19: A previously unknown SARS-related coronavirus (SARS-CoV-2) of pandemic potential infecting humans-Call for a One Health approach. One Health 2020, 9, 100124. [CrossRef]

3. Wu, F.; Wang, A.; Liu, M.; Wang, Q.; Chen, J.; Xia, S.; Ling, Y.; Zhang, Y.; Xun, J.; Lu, L.; et al. Neutralizing antibody responses to SARS-CoV-2 in a COVID-19 recovered patient cohort and their implications. 2020. Available online: https: / / papers.ssrn.com/sol3/papers.cfm?abstract_id=3566211 (accessed on 15 January 2021).

4. Li, F. Structure, Function, and Evolution of Coronavirus Spike Proteins. Annu. Rev. Virol. 2016, 3, 237-261. [CrossRef] [PubMed]

5. Perlman, S.; Netland, J. Coronaviruses post-SARS: Update on replication and pathogenesis. Nat. Rev. Genet. 2009, 7, 439-450. [CrossRef] [PubMed]

6. Li, F. Receptor Recognition Mechanisms of Coronaviruses: A Decade of Structural Studies. J. Virol. 2015, 89, 1954-1964. [CrossRef] [PubMed]

7. Li, W.; Moore, M.J.; Vasilieva, N.; Sui, J.; Wong, S.K.; Berne, M.A.; Somasundaran, M.; Sullivan, J.L.; Luzuriaga, K.; Greenough, T.C.; et al. Angiotensin-converting enzyme 2 is a functional receptor for the SARS coronavirus. Nature 2003, 426, 450-454. [CrossRef] [PubMed]

8. Boopathi, S.; Poma, A.B.; Kolandaivel, P. Novel 2019 coronavirus structure, mechanism of action, antiviral drug promises and rule out against its treatment. J. Biomol. Struct. Dyn. 2020, 1-10. [CrossRef]

9. Heald-Sargent, T.; Gallagher, T. Ready, Set, Fuse! The Coronavirus Spike Protein and Acquisition of Fusion Competence. Viruses 2012, 4, 557-580. [CrossRef]

10. Moreira, R.A.; Chwastyk, M.; Baker, J.L.; Guzman, H.A.V.; Poma, A.B. Quantitative determination of mechanical stability in the novel coronavirus spike protein. Nanoscale 2020, 12, 16409-16413. [CrossRef] 
11. Moreira, R.A.; Guzman, H.V.; Boopathi, S.; Baker, J.L.; Poma, A.B. Characterization of Structural and Energetic Differences between Conformations of the SARS-CoV-2 Spike Protein. Materials 2020, 13, 5362. [CrossRef]

12. Anand, K. Coronavirus Main Proteinase (3CLpro) Structure: Basis for Design of Anti-SARS Drugs. Science 2003, 300, 1763-1767. [CrossRef]

13. Gil, C.; Ginex, T.; Maestro, I.; Nozal, V.; Barrado-Gil, L.; Cuesta-Geijo, M.Á.; Urquiza, J.; Ramírez, D.; Alonso, C.; Campillo, N.E.; et al. COVID-19: Drug Targets and Potential Treatments. J. Med. Chem. 2020, 63, 12359-12386. [CrossRef] [PubMed]

14. Heimfarth, L.; Serafini, M.R.; Martins-Filho, P.R.; Quintans, J.D.S.S.; Quintans-Júnior, L.J. Drug repurposing and cytokine management in response to COVID-19: A review. Int. Immunopharmacol. 2020, 88, 106947. [CrossRef] [PubMed]

15. Chakraborty, R.; Parvez, S. COVID-19: An overview of the current pharmacological interventions, vaccines, and clinical trials. Biochem. Pharmacol. 2020, 180, 114184. [CrossRef]

16. Thota, S.M.; Balan, V.; Sivaramakrishnan, V. Natural products as home-based prophylactic and symptom management agents in the setting of COVID-19. Phytother. Res. 2020, 34, 3148-3167. [CrossRef] [PubMed]

17. Ninfali, P.; Antonelli, A.; Magnani, M.; Scarpa, E.S. Antiviral Properties of Flavonoids and Delivery Strategies. Nutrient 2020, 12, 2534. [CrossRef] [PubMed]

18. Sui, Z.; Salto, R.; Li, J.; Craik, C.; de Montellano, P.R.O. Inhibition of the HIV-1 and HIV-2 proteases by curcumin and curcumin boron complexes. Bioorg. Med. Chem. 1993, 1, 415-422. [CrossRef]

19. Mehla, R.; Bivalkar-Mehla, S.; Chauhan, A. A Flavonoid, Luteolin, Cripples HIV-1 by Abrogation of Tat Function. PLoS ONE 2011, 6, e27915. [CrossRef] [PubMed]

20. Ürményi, F.G.G.; Saraiva, G.D.N.; Casanova, L.M.; Matos, A.D.S.; Camargo, L.M.D.M.; Romanos, M.T.V.; Costa, S.S. Anti-HSV-1 and HSV-2 Flavonoids and a New Kaempferol Triglycoside from the Medicinal Plant Kalanchoe daigremontiana. Chem. Biodivers. 2016, 13, 1707-1714. [CrossRef]

21. Behbahani, M.; Sayedipour, S.; Pourazar, A.; Shanehsazzadeh, M. In vitro anti-HIV-1 activities of kaempferol and kaempferol-7O-glucoside isolated from Securigera securidaca. Res. Pharm. Sci. 2015, 9, 463-469.

22. Mpiana, P.T.; Tshibangu, D.S.; Kilembe, J.T.; Gbolo, B.Z.; Mwanangombo, D.T.; Inkoto, C.L.; Lengbiye, E.M.; Mbadiko, C.M.; Matondo, A.; Bongo, G.N.; et al. Identification of potential inhibitors of SARS-CoV-2 main protease from Aloe vera compounds: A molecular docking study. Chem. Phys. Lett. 2020, 754, 137751. [CrossRef]

23. Rezazadeh, F.; Moshaverinia, M.; Motamedifar, M.; Alyaseri, M. Assessment of Anti HSV-1 Activity of Aloe Vera Gel Extract: An In Vitro Study. J. Dent. 2016, 17, 49-54.

24. Abd-Alla, H.I.; Abu-Gabal, N.S.; Hassan, A.Z.; El-Safty, M.M.; Shalaby, N.M.M. Antiviral activity of Aloe hijazensis against some haemagglutinating viruses infection and its phytoconstituents. Arch. Pharmacal Res. 2012, 35, 1347-1354. [CrossRef]

25. Saoo, K.; Miki, H.; Ohmori, M.; Winters, W.D. Antiviral Activity of Aloe Extracts against Cytomegalovirus. Phytother. Res. 1996, 10, 348-350. [CrossRef]

26. Huang, C.-T.; Hung, C.-Y.; Hseih, Y.-C.; Chang, C.-S.; Velu, A.B.; He, Y.-C.; Huang, Y.-L.; Chen, T.-A.; Chen, T.-C.; Lin, C.-Y.; et al. Effect of aloin on viral neuraminidase and hemagglutinin-specific T cell immunity in acute influenza. Phytomedicine 2019, 64, 152904. [CrossRef] [PubMed]

27. Subbaiyan, A.; Ravichandran, K.; Singh, S.V.; Sankar, M.; Thomas, P.; Dhama, K.; Malik, Y.S.; Singh, R.K.; Chaudhuri, P. In silico Molecular Docking Analysis Targeting SARS-CoV-2 Spike Protein and Selected Herbal Constituents. J. Pure Appl. Microbiol. 2020, 14, 989-998. [CrossRef]

28. Jorgensen, W.L. The Many Roles of Computation in Drug Discovery. Science 2004, 303, 1813-1818. [CrossRef] [PubMed]

29. Ramajayam, R.; Tan, K.-P.; Liang, P.-H. Recent development of 3C and 3CL protease inhibitors for anti-coronavirus and antipicornavirus drug discovery. Biochem. Soc. Trans. 2011, 39, 1371-1375. [CrossRef]

30. Salman, S.; Shah, F.H.; Idrees, J.; Idrees, F.; Velagala, S.; Ali, J.; Khan, A.A. Virtual screening of immunomodulatory medicinal compounds as promising anti-SARS-COV-2 inhibitors. Future Virol. 2020, 15, 267-275. [CrossRef]

31. Simmons, G.; Gosalia, D.N.; Rennekamp, A.J.; Reeves, J.D.; Diamond, S.L.; Bates, P. Inhibitors of cathepsin L prevent severe acute respiratory syndrome coronavirus entry. Proc. Natl. Acad. Sci. USA 2005, 102, 11876-11881. [CrossRef]

32. Al-Bari, M.A.A. Chloroquine analogues in drug discovery: New directions of uses, mechanisms of actions and toxic manifestations from malaria to multifarious diseases. J. Antimicrob. Chemother. 2015, 70, 1608-1621. [CrossRef] [PubMed]

33. Yang, N.; Shen, H.-M. Targeting the Endocytic Pathway and Autophagy Process as a Novel Therapeutic Strategy in COVID-19. Int. J. Biol. Sci. 2020, 16, 1724-1731. [CrossRef]

34. Rivinoja, A.; Hassinen, A.; Kokkonen, N.; Kauppila, A.; Kellokumpu, S. Elevated Golgi pH impairs terminalN-glycosylation by inducing mislocalization of Golgi glycosyltransferases. J. Cell. Physiol. 2009, 220, 144-154. [CrossRef]

35. Li, Z.; Li, X.; Huang, Y.Y.; Wu, Y.; Liu, R.; Zhou, L.; Lin, Y.; Wu, D.; Zhang, L.; Liu, H.; et al. Identify potent SARS-CoV-2 main protease inhibitors via accelerated free energy perturbation-based virtual screening of existing drugs. Proc. Natl. Acad. Sci. USA 2020, 117, 27381-27387. [CrossRef] [PubMed]

36. Velázquez-Libera, J.L.; Durán-Verdugo, F.; Valdés-Jiménez, A.; Núñez-Vivanco, G.; Caballero, J. LigRMSD: A web server for automatic structure matching and RMSD calculations among identical and similar compounds in protein-ligand docking. Bioinformatics 2020, 36, 2912-2914. [CrossRef]

37. Totrov, M.; Abagyan, R. Flexible ligand docking to multiple receptor conformations: A practical alternative. Curr. Opin. Struct. Biol. 2008, 18, 178-184. [CrossRef] [PubMed] 
38. De Vivo, M.; Masetti, M.; Bottegoni, G.; Cavalli, A. Role of Molecular Dynamics and Related Methods in Drug Discovery. J. Med. Chem. 2016, 59, 4035-4061. [CrossRef] [PubMed]

39. De Vivo, M.; Cavalli, A. Recent advances in dynamic docking for drug discovery. Wiley Interdiscip. Rev. Comput. Mol. Sci. 2017, 7, 1320. [CrossRef]

40. Souza, P.C.T.; Thallmair, S.; Conflitti, P.; Ramírez-Palacios, C.; Alessandri, R.; Raniolo, S.; Limongelli, V.; Marrink, S.J. Proteinligand binding with the coarse-grained Martini model. Nat. Commun. 2020, 11, 1-11. [CrossRef] [PubMed]

41. Arokiyaraj, S.; Stalin, A.; Kannan, B.S.; Shin, H. Geranii Herba as a Potential Inhibitor of SARS-CoV-2 Main 3CL pro, Spike RBD, and Regulation of Unfolded Protein Response: An In Silico Approach. Antibiotics 2020, 9, 863. [CrossRef]

42. Hussien, M.A.; Abdelaziz, A.E. Molecular docking suggests repurposing of brincidofovir as a potential drug targeting SARSCoV-2 ACE2 receptor and main protease. Netw. Model. Anal. Health Inform. Bioinformatics 2020, 9, 1-18.

43. Sayed, A.M.; Alhadrami, H.A.; El-Gendy, A.O.; Shamikh, Y.I.; Belbahri, L.; Hassan, H.M.; Abdelmohsen, U.R.; Rateb, M.E. Microbial natural products as potential inhibitors of SARS-CoV-2 main protease (Mpro). Microorganisms 2020, 8, 970. [CrossRef] [PubMed]

44. Saurav, K.; Zhang, W.; Saha, S.; Zhang, H.; Li, S.; Zhang, Q.; Wu, Z.; Zhang, G.; Zhu, Y.; Verma, G. In silico molecular docking, preclinical evaluation of spiroindimicins A-D, lynamicin A and D isolated from deep marine sea derived Streptomyces sp. SCSIO 03032. Interdiscip. Sci. Comput. Life Sci. 2014, 6, 187-196. [CrossRef]

45. Phillips, J.C.; Braun, R.; Wang, W.; Gumbart, J.; Tajkhorshid, E.; Villa, E.; Chipot, C.; Skeel, R.D.; Kalé, L.; Schulten, K. Scalable molecular dynamics with NAMD. J. Comput. Chem. 2005, 26, 1781-1802. [CrossRef]

46. Foti, R.S.; Wahlstrom, J.L. CYP2C19 Inhibition: The Impact of Substrate Probe Selection on in Vitro Inhibition Profiles. Drug Metab. Dispos. 2007, 36, 523-528. [CrossRef] [PubMed]

47. Van Booven, D.; Marsh, S.; McLeod, H.; Carrillo, M.W.; Sangkuhl, K.; Klein, T.E.; Altman, R.B. Cytochrome P450 2C9-CYP2C9. Pharm. Genom. 2010, 20, 277-281. [CrossRef] [PubMed]

48. Bertilsson, L.; Dahl, M.-L.; Dalén, P.; Al-Shurbaji, A. Molecular genetics of CYP2D6: Clinical relevance with focus on psychotropic drugs. Br. J. Clin. Pharmacol. 2002, 53, 111-122. [CrossRef]

49. Dai, D.; Tang, J.; Rose, R.; Hodgson, E.; Bienstock, R.J.; Mohrenweiser, H.W.; A Goldstein, J. Identification of variants of CYP3A4 and characterization of their abilities to metabolize testosterone and chlorpyrifos. J. Pharmacol. Exp. Ther. 2001, 299, 825-831.

50. Wessler, J.D.; Grip, L.T.; Mendell, J.; Giugliano, R.P. The P-Glycoprotein Transport System and Cardiovascular Drugs. J. Am. Coll. Cardiol. 2013, 61, 2495-2502. [CrossRef]

51. Sharom, F.J. Complex Interplay between the P-Glycoprotein Multidrug Efflux Pump and the Membrane: Its Role in Modulating Protein Function. Front. Oncol. 2014, 4, 41. [CrossRef] [PubMed]

52. Singh, S.; Singh, J. Transdermal drug delivery by passive diffusion and iontophoresis: A review. Med. Res. Rev. 1993, 13, 569-621. [CrossRef] [PubMed]

53. Mitragotri, S.; Anissimov, Y.G.; Bunge, A.L.; Frasch, H.F.; Guy, R.H.; Hadgraft, J.; Kasting, G.B.; Lane, M.E.; Roberts, M.S. Mathematical models of skin permeability: An overview. Int. J. Pharm. 2011, 418, 115-129. [CrossRef] [PubMed]

54. Jin, Z.; Du, X.; Xu, Y.; Deng, Y.; Liu, M.; Zhao, Y.; Zhang, B.; Li, X.; Zhang, L.; Peng, C.; et al. Structure of M pro from SARS-CoV-2 and discovery of its inhibitors. Nature 2020, 582, 289-293. [CrossRef]

55. Cozza, G.; Moro, S. Medicinal Chemistry and the Molecular Operating Environment (MOE): Application of QSAR and Molecular Docking to Drug Discovery. Curr. Top. Med. Chem. 2008, 8, 1555-1572. [CrossRef]

56. MacKerell, A.D., Jr.; Bashford, D.; Bellott, M.L.D.R.; Dunbrack, R.L., Jr.; Evanseck, J.D.; Field, M.J.; Fischer, S.; Gao, J.; Guo, H.; Ha, S.; et al. All-atom empirical potential for molecular modeling and dynamics studies of proteins. J. Phys. Chem. B 1998, 102, 3586-3616. [CrossRef] [PubMed]

57. Humphrey, W.; Dalke, A.; Schulten, K. VMD: Visual molecular dynamics. J. Mol. Graph. 1996, 14, 33-38. [CrossRef]

58. Martyna, G.J.; Tobias, D.J.; Klein, M.L. Constant pressure molecular dynamics algorithms. J. Chem. Phys. 1994, 101, 4177-4189. [CrossRef]

59. Jo, S.; Kim, T.; Iyer, V.G.; Im, W. CHARMM-GUI: A web-based graphical user interface for CHARMM. J. Comput. Chem. 2008, 29, 1859-1865. [CrossRef]

60. Jo, S.; Jiang, W.; Lee, H.S.; Roux, B.; Im, W. CHARMM-GUI Ligand Binder for Absolute Binding Free Energy Calculations and Its Application. J. Chem. Inf. Model. 2013, 53, 267-277. [CrossRef] [PubMed]

61. Salentin, S.; Schreiber, S.; Haupt, V.J.; Adasme, M.F.; Schroeder, M. PLIP: Fully automated protein-ligand interaction profiler. Nucleic Acids Res. 2015, 43, W443-W447. [CrossRef]

62. Allam, A.E.; Assaf, H.K.; Hassan, H.A.; Shimizu, K.; Elshaier, Y.A.M.M. An in silico perception for newly isolated flavonoids from peach fruit as privileged avenue for a countermeasure outbreak of COVID-19. RSC Adv. 2020, 10, 29983-29998. [CrossRef]

63. Ibrahim, A.K.; Youssef, A.I.; Arafa, A.S.; Ahmed, S.A. Anti-H5N1 virus flavonoids fromCapparis sinaicaVeill. Nat. Prod. Res. 2013, 27, 2149-2153. [CrossRef] [PubMed]

64. Van Vuong, Q.; Nguyen, T.T.; Li, M.S. A New Method for Navigating Optimal Direction for Pulling Ligand from Binding Pocket: Application to Ranking Binding Affinity by Steered Molecular Dynamics. J. Chem. Inf. Model. 2015, 55, 2731-2738. [CrossRef] [PubMed]

65. Abdissa, D.; Geleta, G.; Bacha, K.; Abdissa, N. Phytochemical investigation of Aloe pulcherrima roots and evaluation for its antibacterial and antiplasmodial activities. PLoS ONE 2017, 12, e0173882. [CrossRef] [PubMed] 
66. Abdissa, N.; Induli, M.; Fitzpatrick, P.; Alao, J.P.; Sunnerhagen, P.; Landberg, G.; Yenesew, A.; Erdélyi, M. Cytotoxic Quinones from the Roots of Aloe dawei. Molecules 2014, 19, 3264-3273. [CrossRef]

67. Abdissa, N.; Gohlke, S.; Frese, M.; Sewald, N. Cytotoxic Compounds from Aloe megalacantha. Molecules 2017, 22, 1136. [CrossRef]

68. Zhong, J.; Huang, Y.; Ding, W.; Wu, X.; Wan, J.; Luo, H. Chemical constituents of Aloe barbadensis Miller and their inhibitory effects on phosphodiesterase-4D. Fitoterapia 2013, 91, 159-165. [CrossRef]

69. Sun, Y.N.; Li, L.Y.; Li, W.; Kang, J.S.; Hwang, I.; Kim, Y.H. Chemical Components from Aloe and their Inhibition of Indoleamine 2, 3-dioxygenase. Pharmacogn. Mag. 2017, 13, 58-63.

70. Kurizaki, A.; Watanabe, T.; Devkota, H.P. Chemical Constituents from the Flowers of Aloe arborescens. Nat. Prod. Commun. 2019, 14, 1934578-19844135. [CrossRef]

71. Koyama, J.; Ogura, T.; Tagahara, K. Naphtho[2,3-c]furan-4,9-dione and its derivatives from Aloe ferox. Phytochemistry 1994, 37, 1147-1148. [CrossRef]

72. Rehman, N.U.; Al-Riyami, S.A.; Hussain, H.; Ali, A.; Khan, A.L.; Al-Harrasi, A. Secondary metabolites from the resins of Aloe vera and Commiphora mukul mitigate lipid peroxidation. Acta Pharm. 2019, 69, 433-441. [CrossRef]

73. Sigler, A.; Rauwald, H.W. Aloe Plants Accumulate Anthrone-Type Anthranoids in Inflorescence and Leaves, and Tetrahydroanthracenes in Roots. Z. Nat. C 1994, 49, 286-292. [CrossRef]

74. Van Oudtshoorn, M.v.R. Chemotaxonomic investigations in asphodeleae and aloineae (liliaceae). Phytochemistry 1964, 3, 383-390. [CrossRef]

75. Kambizi, L.; Sultana, N.; Afolayan, A. Bioactive Compounds Isolated fromAloe ferox.: A Plant Traditionally Used for the Treatment of Sexually Transmitted Infections in the Eastern Cape, South Africa. Pharm. Biol. 2005, 42, 636-639. [CrossRef]

76. Awe, W.; Kuemmell, H. On the occurrence of aloin in Aloe vera in addition to comparative studies with the fresh juice of Cape aloe (Aloe ferox) and the dried extract prepared from it. Arch. Pharm. 1962, 295, 819-822. [CrossRef]

77. Hirata, T.; Suga, T. Biologically Active Constituents of Leaves and Roots of Aloe arborescens var. natalensis. Z. Nat. C 1977, 32, 731-734. [CrossRef]

78. Yagi, A.; Makino, K.; Nishioka, I. Studies on the Constituents of Aloe sapnaria HAW. I. The Structures of Tetrahydroanthracene Derivatives and the Related Anthraquinones. Chem. Pharm. Bull. 1974, 22, 1159-1166. [CrossRef]

79. Yagi, A.; Makino, K.; Nishioka, I. Studies on the constituents of Aloe saponaria Haw. II. The structures of tetrahydroanthracene derivatives, aloesaponol III and -IV. Chem. Pharm. Bull. 1977, 25, 1764-1770. [CrossRef]

80. Yagi, A.; Makino, K.; Nishioka, I. Studies on the constituents of Aloe saponaria Haw. III. The structures of phenol glucosides. Chem. Pharm. Bull. 1977, 25, 1771-1776. [CrossRef]

81. Yagi, A.; Makino, K.; Nishioka, I. Studies on the constituents of Aloe saponaria Haw. IV. The structures of bianthraquinoid pigments. Chem. Pharm. Bull. 1978, 26, 1111-1116. [CrossRef]

82. Abd-Alla, H.I.; Shaaban, M.; Shaaban, K.A.; Abu-Gabal, N.S.; Shalaby, N.M.; Laatsch, H. New bioactive compounds fromAloe hijazensis. Nat. Prod. Res. 2009, 23, 1035-1049. [CrossRef]

83. Epifano, F.; Fiorito, S.; Locatelli, M.; Taddeo, V.A.; Genovese, S. Screening for novel plant sources of prenyloxyanthraquinones: Senna alexandrina Mill. and Aloe vera (L.) Burm. F. Nat. Prod. Res. 2015, 29, 180-184. [CrossRef]

84. Van Wyk, B.-E.; Wink, M. Medicinal Plants of the World; CABI: Wallingford, England, 2018.

85. Conner, J.M.; Gray, A.I.; Reynolds, T.; Waterman, P.G. Anthraquinone, anthrone and phenylpyrone components of Aloe nyeriensis var. kedongensis leaf exudate. Phytochemistry 1987, 26, 2995-2997. [CrossRef]

86. Rehman, N.U.; Khan, A.; Al-Harrasi, A.; Khiat, M.; Hussain, H.; Wadood, A.; Riaz, M. Natural urease inhibitors from Aloe vera resin and Lycium shawii and their structural-activity relationship and molecular docking study. Bioorg. Chem. 2019, 88, 102955. [CrossRef]

87. Conner, J.M.; Gray, A.I.; Waterman, P.G.; Reynolds, T. Novel Anthrone-Anthraquinone Dimers from Aloe elgonica. J. Nat. Prod. 1990, 53, 1362-1364. [CrossRef]

88. Shin, K.H.; Woo, W.S.; Lim, S.S.; Shim, C.S.; Chung, H.S.; Kennelly, E.J.; Kinghorn, A.D. Elgonica-Dimers A and B, Two Potent Alcohol Metabolism Inhibitory Constituents of Aloe arborescens. J. Nat. Prod. 1997, 60, 1180-1182. [CrossRef]

89. Saleem, R.; Faizi, S.; Hussain, S.A.; Qazi, A.; Dar, A.; Ahmad, S.I.; Qazi, M.; Akhtar, S.; Hasnain, S.N.; Siddiqui, B.S.; et al. Hypotensive Effect of Chemical Constituents fromAloe barbadensis. Planta Med. 2001, 67, 757-760. [CrossRef] [PubMed]

90. Auterhoff, H.; Graf, E.; Eurisch, G.; Alexa, M. Trennung des Aloins in Diastereomere und deren Charakterisierung. Arch. Pharm. 1980, 313, 113-120. [CrossRef]

91. Tekassa, T.; Tewabe, Y.; Bisrat, D.; Hailu, A.; Asres, K. Antileishmanial activities of leaf latex and compound isolated from Aloe ghibensis Sebsebe \& Friis. Ethiop. Pharm. J. 2020, 35, 51-58. [CrossRef]

92. Aldayel, T.S.; Grace, M.H.; Lila, M.A.; Yahya, M.A.; Omar, U.M.; Alshammary, G. LC-MS characterization of bioactive metabolites from two Yemeni Aloe spp. with antioxidant and antidiabetic properties. Arab. J. Chem. 2020, 13, 5040-5049. [CrossRef]

93. Megeressa, M.; Bisrat, D.; Mazumder, A.; Asres, K. Structural elucidation of some antimicrobial constituents from the leaf latex of Aloe trigonantha L.C. Leach. BMC Complement. Altern. Med. 2015, 15, 270. [CrossRef] [PubMed]

94. Teka, T.; Kassahun, H. Characterization and Evaluation of Antioxidant Activity of Aloe schelpei Reynolds. Drug Des. Dev. Ther. 2020, ume 14, 1003-1008. [CrossRef]

95. Kassahun, A.; Bisrat, D. Free radical scavenging activities of three anthrones from Aloe gilbertii reynolds leaf latex. J. Nat. Prod. Plant Resour. 2017, 7, 40-44. 
96. Abeje, F.; Bisrat, D.; Hailu, A.; Asres, K. Phytochemistry and Antileishmanial Activity of the Leaf Latex ofAloe calidophilaReynolds. Phytother. Res. 2014, 28, 1801-1805. [CrossRef]

97. Okamura, N.; Hine, N.; Harada, S.; Fujioka, T.; Mihashi, K.; Nishi, M.; Miyahara, K.; Yagi, A. Diastereomeric C-glucosylanthrones of Aloe vera leaves. Phytochemistry 1997, 45, 1519-1522. [CrossRef]

98. Grace, O.; Kokubun, T.; Veitch, N.; Simmonds, M. Characterisation of a nataloin derivative from Aloe ellenbeckii, a maculate species from east Africa. South. Afr. J. Bot. 2008, 74, 761-763. [CrossRef]

99. Rauwald, H.W.; Beil, A. 5-Hydroxyaloin A in the Genus Aloe Thin Layer Chromatographic Screening and High Performance Liquid Chromatographic Determination. Z. Nat. C 1993, 48, 1-4. [CrossRef]

100. Asres, K.; Girma, B.; Bisrat, D. Antimalarial evaluation of the leaf latex of Aloe citrina and its major constituent. Anc. Sci. Life 2015, 34, 142-146. [CrossRef]

101. Mebe, P.P. 2'-p-Methoxycoumaroylaloeresin, A C-glucoside from Aloe excelsa. Phytochemistry 1987, 26, 2646-2647. [CrossRef]

102. Beaumont, J.; Reynolds, R.; Vaughan, J.G. Homonataloin in Aloe species. Planta Med. 1984, 50, 505-508. [CrossRef]

103. Dagne, E.; Bisrat, D.; Van Wyk, B.-E.; Viljoen, A.; Hellwig, V.; Steglich, W. Anthrones from Aloe microstigma. Phytochemistry 1997, 44, 1271-1274. [CrossRef]

104. Lv, L.; Tian, X.-Y.; Fang, W.-S. Three new antioxidantC-glucosylanthrones fromAloe nobilis. J. Asian Nat. Prod. Res. 2010, 12, 443-447. [CrossRef]

105. Bisrat, D.; Dagne, E.; Van Wyk, B.-E.; Viljoen, A. Chromones and anthrones from Aloe marlothii and Aloe rupestris. Phytochemistry 2000, 55, 949-952. [CrossRef]

106. Sigler, A.; Rauwald, H.W. First proof of anthrone aglycones and diastereomeric anthrone-C-glycosyls in flowers and bracts of Aloe species. Biochem. Syst. Ecol. 1994, 22, 287-290. [CrossRef]

107. Hoerhammer, L.; Wagner, H.; Bittner, G. ALOINOSIDE B, A NEW GLYCOSIDE FROM ALOE. Z. Nat. B 1964, 19 , $222-226$.

108. Gao, J.; Zhang, G.; Dai, R.; Bi, K. Isolation of Aloinoside B and Metabolism by Rat Intestinal Bacteria. Pharm. Biol. 2005, 42, 581-587. [CrossRef]

109. Viljoen, A.M.; Van Wyk, B.-E.; Van Heerden, F.R. The chemotaxonomic value of the diglucoside anthrone homonataloside B in the genus Aloe. Biochem. Syst. Ecol. 2002, 30, 35-43. [CrossRef]

110. Farah, M.; Andersson, R.; Samuelsson, G. Microdontin A and B: Two New Aloin Derivatives from Aloe microdonta. Planta Med. 1992, 58, 88-93. [CrossRef]

111. Zhong, J.-S.; Huang, Y.-Y.; Zhang, T.-H.; Liu, Y.-P.; Ding, W.-J.; Wu, X.-F.; Xie, Z.-Y.; Luo, H.-B.; Wan, J.-Z. Natural phosphodiesterase-4 inhibitors from the leaf skin of Aloe barbadensis Miller. Fitoterapia 2015, 100, 68-74. [CrossRef]

112. Dagne, E.; Bisrat, D.; Van Wyk, B.-E.; Viljoen, A. 10-Hydroxyaloin B 6'-O-Acetate, an Oxanthrone fromAloe claviflora. J. Nat. Prod. 1998, 61, 256-257. [CrossRef]

113. Dagne, E.; Van Wyk, B.-E.; Stephenson, D.; Steglich, W. Three oxanthrones from Aloe littoralis. Phytochemistry 1996, $42,1683-1687$. [CrossRef]

114. Dagne, E.; Bisrat, D.; Codina, C.; Bastida, J. A C,O-diglucosylated oxanthrone from Aloe littoralis. Phytochemistry 1998, 48, 903-905. [CrossRef]

115. Wang, H.M.; Shi, W.; Xu, Y.K.; Wang, P.; Chen, W.; Liu, Y.; Lu, M.J.; Pa, J.Q. Isolation and spectral study of 4-methyl-6, 8-dihydroxy-7H-benz [de] anthracen-7-one. Magn. Reson. Chem. 2003, 41, 301-303. [CrossRef]

116. Asamenew, G.; Bisrat, D.; Mazumder, A.; Asres, K. In Vitro Antimicrobial and Antioxidant Activities of Anthrone and Chromone from the Latex of Aloe harlana Reynolds. Phytother. Res. 2011, 25, 1756-1760. [CrossRef] [PubMed]

117. Saleem, R.; Faizi, S.; Deeba, F.; Siddiqui, B.S.; Qazi, M.H. Anthrones from Aloe barbadensis. Phytochemistry 1997, 45, 1279-1282. [CrossRef]

118. Yagi, A.; Shoyama, Y.; Nishioka, I. Formation of tetrahydroanthracene glucosides by callus tissue of Aloe saponaria. Phytochemistry 1983, 22, 1483-1484. [CrossRef]

119. Yagi, A.; Hine, N.; Asai, M.; Nakazawa, M.; Tateyama, Y.; Okamura, N.; Fujioka, T.; Mihashi, K.; Shimomura, K. Tetrahydroanthracene glucosides in callus tissue from Aloe barbadensis leaves. Phytochemistry 1998, 47, 1267-1270. [CrossRef]

120. Yenesew, A.; Ogur, J.; Duddeckt, H. (R)-Prechrysophanol from Aloe graminicola. Phytochemistry 1993, 34, 1442-1444. [CrossRef]

121. Dagne, E.; Casser, I.; Steglich, W. Aloechrysone, a dihydroanthracenone from Aloe berhana. Phytochemistry 1992, 31, 1791-1793. [CrossRef]

122. Abe, I.; Oguro, S.; Utsumi, Y.; Sano, Y.; Noguchi, H. Engineered Biosynthesis of Plant Polyketides: Chain Length Control in an Octaketide-Producing Plant Type III Polyketide Synthase. J. Am. Chem. Soc. 2005, 127, 12709-12716. [CrossRef]

123. Sun, Y.N.; Li, W.; Yang, S.Y.; Kang, J.S.; Ma, J.Y.; Kim, Y.H. Isolation and identification of chromone and pyrone constituents from Aloe and their anti-inflammatory activities. J. Funct. Foods 2016, 21, 232-239. [CrossRef]

124. Holdsworth, D. Chromones in Aloe species-Part II-Aloesone. Planta Med. 1972, 22, 54-58. [CrossRef]

125. Conner, J.M.; Gray, A.I.; Reynolds, T.; Waterman, P.G. Anthrone and chromone components of Aloe cremnophila and A. jacksonii leaf exudates. Phytochemistry 1990, 29, 941-944. [CrossRef]

126. Speranza, G.; Fontana, G.; Zanzola, S.; Di Meo, A. Studies on Aloe. 15.1Two New 5-Methylchromones from Cape Aloe. J. Nat. Prod. 1997, 60, 692-694. [CrossRef]

127. Durı, L.; Morelli, C.; Crippa, S.; Speranza, G. 6-Phenylpyrones and 5-methylchromones from Kenya aloe. Fitoterapia 2004, 75, 520-522. [CrossRef] [PubMed] 
128. Blitzke, T.; Masaoud, M.; Schmidt, J. Constituents of Aloe rubroviolacea. Fitoterapia 2001, 72, 78-79. [CrossRef]

129. Okamura, N.; Hine, N.; Harada, S.; Fujioka, T.; Mihashi, K.; Yagi, A. Three chromone components from Aloe vera leaves. Phytochemistry 1996, 43, 495-498. [CrossRef]

130. Okamura, N.; Hine, N.; Tateyama, Y.; Nakazawa, M.; Fujioka, T.; Mirmhi, K.; Yagi, A. Three chromones of Aloe vera leaves. Phytochemistry 1997, 45, 1511-1513. [CrossRef]

131. Okamura, N.; Hine, N.; Tateyama, Y.; Nakazawa, M.; Fujioka, T.; Mihashi, K.; Yagi, A. Five chromones from Aloe Vera leaves. Phytochemistry 1998, 49, 219-223. [CrossRef]

132. Kahramanoğlu, I.; Chen, C.; Chen, J.; Wan, C. Chemical Constituents, Antimicrobial Activity, and Food Preservative Characteristics of Aloe vera Gel. Agronomy 2019, 9, 831. [CrossRef]

133. Yuan, A.X.; Kang, S.H.; Qin, L.; Yuan, P.; Fan, Y.J. Chemical constituents of the leaves of Chinese aloe (Aloe vera var. chinensis). Zhongcaoyao 1994, 25, 339-341.

134. Park, M.; Park, J.; Shin, Y.; Kim, W.; Lee, J.; Kim, K. Neoaloesin A: A NewC-Glucofuranosyl Chromone fromAloe barbadensis. Planta Med. 1996, 62, 363-365. [CrossRef] [PubMed]

135. Haynes, L.; Holdsworth, D.; Russell, R. C-Glycosyl compounds. Part VI. Aloesin, a C-glucosylchromone from Aloe sp. J. Chem. Soc. C Org. 1970, 2581-2586. [CrossRef]

136. Wu, X.-F.; Wan, J.-Z.; Luo, B.-J.; Yang, M.-R.; Ding, W.-J.; Zhong, J.-S. A novel naphthalene derivative from Aloe barbadensis. Yao xue xue bao = Acta Pharm. Sin. 2013, 48, 723-727.

137. Hiruy, M.; Bisrat, D.; Mazumder, A.; Asres, K. Two chromones with antimicrobial activity from the leaf latex of Aloe monticola Reynolds. Nat. Prod. Res. 2021, 35, 1052-1056. [CrossRef]

138. Lv, L.; Yang, Q.Y.; Zhao, Y.; Yao, C.S.; Sun, Y.; Yang, E.J.; Song, K.S.; Mook-Jung, I.; Fang, W.S. BACE1 (beta-secretase) inhibitory chromone glycosides from Aloe vera and Aloe nobilis. Planta Med. 2008, 74, 540-545. [CrossRef]

139. Hutter, J.A.; Salman, M.; Stavinoha, W.B.; Satsangi, N.; Williams, R.F.; Streeper, R.T.; Weintraub, S.T. AntiinflammatoryC-Glucosyl Chromone fromAloe barbadensis. J. Nat. Prod. 1996, 59, 541-543. [CrossRef]

140. Speranza, G.; Gramatica, P.; Dadá, G.; Manitto, P. Aloeresin C, a bitter C, O-diglucoside from Cape Aloe. Phytochemistry 1985, 24, 1571-1573. [CrossRef]

141. Speranza, G.; Dada, G.; Lunazzi, L.; Gramatica, P.; Manitto, P. A C-glucosylated 5-methylchromone from Kenya aloe. Phytochemistry 1986, 25, 2219-2222. [CrossRef]

142. Conner, J.M.; Gray, A.I.; Reynolds, T.; Waterman, P.G. Anthracene and chromone derivatives in the exudate of Aloe rabaiensis. Phytochemistry 1989, 28, 3551-3553. [CrossRef]

143. Van Heerden, F.R.; Van Wyk, B.-E.; Viljoen, A.M. ChemInform Abstract: Aloeresins E (Ia) and F (Ib), Two Chromone Derivatives from Aloe Peglerae. ChemInform 2010, 28, 867-869. [CrossRef]

144. Van Heerden, F.R.; Viljoen, A.M.; van Wyk, B.E. 6'-O-Coumaroylaloesin from Aloe castanea-a taxonomic marker for Aloe section Anguialoe. Phytochemistry 2000, 55, 117-120. [CrossRef]

145. Holzapfel, C.W.; Wessels, P.L.; Van Wyk, B.-E.; Marais, W.; Portwig, M. Chromone and aloin derivatives from Aloe broomii, A. Africana and A. speciosa. Phytochemistry 1997, 45, 97-102. [CrossRef]

146. Gramatica, P.; Monti, D.; Speranza, G.; Manitto, P. Aloe revisited the structure of aloeresin A. Tetrahedron Lett. 1982, $23,2423-2424$. [CrossRef]

147. Speranza, G.; Martignoni, A.; Manitto, P. Iso-aloeresin A, a Minor Constituent of Cape Aloe. J. Nat. Prod. 1988, 51, 588-590. [CrossRef]

148. Makino, K.; Yagi, A.; Nishioka, I. Studies on the constituents of Aloe arborescens Mill. var. natalensis Berger. II. The structures of two new aloesin esters. Chem. Pharm. Bull. 1974, 22, 1565-1570. [CrossRef]

149. Xiao, Z.; Chen, D.; Si, J.; Tu, G.; Ma, L. Chemical constituents of Aloe vera. Yaoxue Xuebao 2000, 35, 120-123.

150. Manitto, P.; Speranza, G.; De Tommasi, N.; Ortoleva, E.; Morelli, C.F. Aloeresin H, a new polyketide constituent of Cape aloe. Tetrahedron 2003, 59, 401-408. [CrossRef]

151. Speranza, G.; Morelli, C.F.; Tubaro, A.; Altinier, G.; Durì, L.; Manitto, P. Aloeresin I, an Anti-Inflammatory 5-Methylchromone from Cape Aloe. Planta Med. 2005, 71, 79-81. [CrossRef]

152. Yuan, A.X. The molecular structure of iso-aloesin isolated from the leaves of Aloe vera L. var. chinensis (Haw.) Berge. China J. Chin. Mater. Med. 1993, 18, 609-611.

153. Bhaludra, C.S.S.; Bethapudi, R.R.; Murugulla, A.C.; Pullagummi, C.; Latha, T.; Venkatesh, K.; Bheemagani, A.J.; Pudutha, A.; Rani, A.R. Cultivation, phytochemical studies, biological activities and medicinal uses of Aloe ferox, grandfather of aloes an important amazing medicinal plant. Int. J. Pharmacol. 2013, 9, 405-415.

154. López, A.; De Tangil, M.S.; Vega-Orellana, O.; Ramírez, A.S.; Rico, M. Phenolic Constituents, Antioxidant and Preliminary Antimycoplasmic Activities of Leaf Skin and Flowers of Aloe vera (L.) Burm. f. (syn. A. barbadensis Mill.) from the Canary Islands (Spain). Molecules 2013, 18, 4942-4954. [CrossRef] [PubMed]

155. Saxena, V.; Sharma, D. 5, 4'-dihydroxy 6, 7, 3', 5'-tetramethoxy flavone 5-O-alpha-L-rhamno pyranosyl 16-O-beta-Dgalactopyranoside from aloe barbadensis (leaves). J. Inst. Chem. 1998, 70, 179-182.

156. Sexena, V.; Chourasia, S. 7-Hydroxy, 6, 3',4'-Trimethoxy Isoflavone-5-O-alpha-L-Rhamnopy-ranosyl[1 $\rightarrow 6$ ]-O-beta-DGlucopyranoside of Aloe vera. J. Inst. Chem. 2000, 72, 195-197. 
157. Kametani, S.; Kojima-Yuasa, A.; Kikuzaki, H.; Kennedy, D.O.; Honzawa, M.; Matsui-Yuasa, I. Chemical Constituents of Cape Aloe and Their Synergistic Growth-Inhibiting Effect on Ehrlich Ascites Tumor Cells. Biosci. Biotechnol. Biochem. 2007, 71, 1220-1229. [CrossRef]

158. Makino, K.; Yagi, A.; Nishioka, I. Studies on the Constituents of Aloe arborescens MILL. var. natalensis BERGER. I. The Structure of Aloearbonaside, a Glucoside of a New Type naturally Occurring Chromene. Chem. Pharm. Bull. 1973, 21, 149-156. [CrossRef]

159. Speranza, G.; Dadá, G.; Lunazzi, L.; Gramatica, P.; Manitto, P. Aloenin B, a New Diglucosylated 6-Phenyl-2-pyrone from Kenya Aloe. J. Nat. Prod. 1986, 49, 800-805. [CrossRef]

160. Shi, S.-P.; Wanibuchi, K.; Morita, H.; Endo, K.; Noguchi, H.; Abe, I. Enzymatic Formation of Unnatural Novel Chalcone, Stilbene, and Benzophenone Scaffolds by Plant Type III Polyketide Synthase. Org. Lett. 2009, 11, 551-554. [CrossRef] [PubMed]

161. Zhang, X.-F.; Wang, H.-M.; Song, Y.-L.; Nie, L.-H.; Wang, L.-F.; Liu, B.; Shen, P.-P.; Liu, Y. Isolation, structure elucidation, antioxidative and immunomodulatory properties of two novel dihydrocoumarins from Aloe vera. Bioorg. Med. Chem. Lett. 2006, 16, 949-953. [CrossRef] [PubMed]

162. Speranza, G.; Manitto, P.; Cassara', P.; Monti, D. Feralolide, a dihydroisocoumarin from cape aloe. Phytochemistry 1993, 33, 175-178. [CrossRef]

163. Rehman, N.U.; Hussain, H.; Khiat, M.; Khan, H.Y.; Abbas, G.; Green, I.R.; Al-Harrasi, A. Bioactive chemical constituents from the resin of Aloe vera. Z. Nat. B 2017, 72, 955-958. [CrossRef]

164. Wang, H.M.; Shi, W.; Xu, Y.K.; Liu, Y.; Lü, M.J.; Pan, J.Q. Spectral study of a new dihydroisocoumarin. Magn. Reson. Chem. 2003, 41, 718-720. [CrossRef]

165. Veitch, N.C.; Simmonds, M.S.; Blaney, W.M.; Reynolds, T. A dihydroisocoumarin glucoside from Aloe hildebrandtii. Phytochemistry 1994, 35, 1163-1166. [CrossRef]

166. Saleem, R.; Faizi, S.; Deeba, F.; Siddiqui, B.S.; Qazi, M.H. A New Bisbenzopyran fromAloe barbadensisRoots. Planta Med. 1997, 63, 454-456. [CrossRef] [PubMed]

167. Dagne, E.; Yenesew, A.; Asmellash, S.; Demissew, S.; Mavi, S. Anthraquinones, pre-anthraquinones and isoeleutherol in the roots of Aloe species. Phytochemistry 1994, 35, 401-406. [CrossRef]

168. Kong, W.-S.; Li, J.; Liu, X.; Mi, Q.-L.; Chen, J.-H.; Li, X.-M.; Yang, G.-Y.; Hu, Q.-F.; Li, T.; Yang, Y.-K. A new naphthalene derivative from Aloe vera and its antibacterial activity. China J. Chin. Mater. Med. 2017, 42, 3761-3763.

169. Wessels, P.L.; Holzapfel, C.W.; Van Wyk, B.-E.; Marais, W. Plicataloside, an O,O-diglycosylated naphthalene derivative from Aloe plicatilis. Phytochemistry 1996, 41, 1547-1551. [CrossRef]

170. Speranza, G.; Monti, D.; Crippa, S.; Cairoli, P.; Morelli, C.F.; Manitto, P. Kenyaloside, a Novel O,O,O-Triglycosylated Naphthalene Derivative from the Exudate of Kenyan Aloe Species. Nat. Prod. Commun. 2006, 1, 1085-1088. [CrossRef]

171. Yang, Q.-Y.; Yao, C.-S.; Fang, W.-S. A new triglucosylated naphthalene glycoside from Aloe vera L. Fitoterapia $2010,81,59-62$. [CrossRef]

172. Speranza, G.; Di Meo, A.; Manitto, P.; Monti, D.; Fontana, G. A New Benzochromanone Derivative from Cape Aloet. J. Agric. Food Chem. 1996, 44, 274-277. [CrossRef]

173. Blitzke, T.; Porzel, A.; Masaoud, M.; Schmidt, J. A chlorinated amide and piperidine alkaloids from Aloe sabaea. Phytochemistry 2000, 55, 979-982. [CrossRef]

174. Hotti, H.; Häkkinen, S.T.; Seppänen-Laakso, T.; Rischer, H. Polyketide-Derived Alkaloids and Anthraquinones in Aloe Plants and Cell Cultures. J. Plant. Biotechnol. Res. 2019, 1, 1-15. [CrossRef] [PubMed]

175. Dagne, E.; Bisrat, D.; Viljoen, A.; Van Wyk, B.-E. Chemistry of Aloe Species. Curr. Org. Chem. 2000, 4, 1055-1078. [CrossRef]

176. Prasannaraja, C.; Kamalanathan, A.S.; Vijayalakshmi, M.A.; Venkataraman, K. A dipyrrole derivative from Aloe vera inhibits an anti-diabetic drug target Dipeptidyl Peptidase (DPP)-IV in vitro. Prep. Biochem. Biotechnol. 2020, 50, 511-520. [CrossRef]

177. Speranza, G.; Corti, S.; Manitto, P. Isolation and Chemical Characterization of a New Constituent of Cape Aloe Having the 1,1-Diphenylethane Skeleton. J. Agric. Food Chem. 1994, 42, 2002-2006. [CrossRef]

178. Confalone, P.N.; Huie, E.M.; Patel, N.G. ChemInform Abstract: The isolation, structure determination, and synthesis of pluridone, a novel insecticide from aloe pluridens. Chem. Inf. 1984, 15, 5563-5566. [CrossRef]

179. Speranza, G.; Manitto, P.; Monti, D.; Lianza, F. Feroxidin, a novel 1-methyltetralin derivative isolated from cape aloe. Tetrahedron Lett. 1990, 31, 3077-3080. [CrossRef]

180. Speranza, G.; Paolo, M.; Donata, P.; Diego, M. Absolute configuration of feroxidin: An experimental support to Snatzke's helicity rules for tetralins. Chirality 1991, 3, 263-267. [CrossRef]

181. Speranza, G.; Manitto, P.; Monti, D.; Pezzuto, D. Studies on Aloe, Part 10. Feroxins A and B, Two O-Glucosylated 1-Methyltetralins from Cape Aloe. J. Nat. Prod. 1992, 55, 723-729. [CrossRef]

182. Esua, M.F.; Rauwald, J.-W. Novel bioactive maloyl glucans from Aloe vera gel: Isolation, structure elucidation and in vitro bioassays. Carbohydr. Res. 2006, 341, 355-364. [CrossRef] [PubMed] 